\title{
LEGAL CHALLENGES FOR THE EUROPEAN UNION CONCERNING AN INTERNATIONAL TREATY ON BUSINESS AND HUMAN RIGHTS
}

\author{
ONDREJ BLAŽO' \\ Institute of European Law \\ ondrej.blazo@flaw.uniba.sk \\ ADAM MÁČAJ² \\ Institute of European Law \\ adam.macaj@flaw.uniba.sk
}

\author{
Cómo citar/Citation \\ O. Blažo y A. Máčaj (2021). \\ Legal challenges for the European Union concerning \\ an International Treaty on Business and Human Rights. \\ Revista de Derecho Comunitario Europeo, 70, 933-978. \\ doi: https://doi.org/10.18042/cepc/rdce.70.04
}

\section{Abstract}

Human rights violations perpetrated by business enterprises are a reality that has been topic of international law and human rights bodies for considerable period of time. Over the years, proposals and instruments of various character were contemplated to regulate corporate conduct. All have been subject of intense scrutiny and became contentious points between states involved in the negotiations. The only document ever adopted by consensus within the United Nations were Guiding

1 Associate Professor of European Law and Director of Institute of European Law, Faculty of Law, Comenius University in Bratislava. The authors prepared the paper within the activities of Jean Monnet Centre of Excellence "Rule of Law in the European Union" supported by the European Union (grant No 620758-EPP-1-2020-1-SK-EPPJMO-CoE).

2 PhD candidate, Institute of European Law, Faculty of Law, Comenius University in Bratislava. 
Principles on Business and Human Rights, adopted as non-binding rules. However, the attempts to produce an international treaty never ceased and are currently debated, with considerable participation of the EU. The aim of this paper is to analyse progress in the developing framework of business relations to human rights, consider the EU involvement, and determine whether the EU can further advance the standards of protection, especially whether it has competence to conclude the potential future agreement on business and human rights, and what approaches are feasible for the EU to implement such agreement into its legal order.

\section{Keywords}

Human rights; European Union; international treaty; corporate social responsibility; due diligence.

\section{DESAFÍOS JURÍDICOS PARA LA UNIÓN EUROPEA EN RELACIÓN CON UN TRATADO INTERNACIONAL SOBRE EMPRESAS Y LOS DERECHOS HUMANOS}

\section{Resumen}

Las violaciones de los derechos humanos perpetradas por empresas son una realidad que ha sido un tema de derecho internacional y órganos de los derechos humanos por un período considerable. A lo largo de los años, se contemplaron diversas propuestas e instrumentos de carácter diverso para la regulación de la conducta empresarial. Todos son objeto de un intenso escrutinio y se han convertido en elementos polémicos entre los Estados involucrados en las negociaciones. El único documento adoptado por consenso en las Naciones Unidas, los Principios Rectores sobre Empresas y Derechos Humanos, contiene reglas no vinculantes. Sin embargo, los intentos de producir un tratado internacional vinculante nunca cesaron y actualmente se debaten con una participación considerable de la Unión Europea (UE). El objetivo de este artículo es analizar el progreso en el marco de desarrollo de las relaciones de las actividades comerciales con los derechos humanos, considerar la participación de la UE y determinar si la UE puede seguir avanzando en el estándar de protección, especialmente si tiene competencia suficiente para concluir el posible acuerdo de empresas y derechos humanos y qué enfoques son viables para que la UE implemente dicho acuerdo en su ordenamiento jurídico.

\section{Palabras clave}

Derechos humanos; Unión Europea; tratado internacional; responsabilidad social corporativa; debida diligencia. 


\section{LES DEFIS JURIDIQUES POUR L'UNION EUROPEENNE CONCERNANT UN TRAITE INTERNATIONAL SUR LES ENTREPRISES ET LES DROITS DE L'HOMME}

\section{Résumé}

Les violations des droits humains par les entreprises sont une réalité qui fait l'objet du droit international et des organes des droits humains depuis un certain temps. Au fil des ans, des propositions et des instruments de nature diverse ont été envisagés pour réglementer la conduite des entreprises. Tous ont fait l'objet d'un examen minutieux et sont devenus un point de discorde entre les États impliqués dans les négociations. Le seul document adopté par consensus au sein de l'ONU sont les Principes directeurs relatifs aux entreprises et aux droits de l'homme, qui ont été adoptés en tant que norme non contraignante. Cependant, les tentatives d'élaboration d'un traité international contraignant n'ont jamais cessé et sont actuellement discutées avec une implication considérable de l'UE. L'objectif de cet article est d'analyser les progrès dans le cadre de développement des relations d'affaires aux droits de l'homme, d'examiner l'implication de l'UE et de déterminer si l'UE peut faire progresser les normes de protection. En particulier, si elle est compétente pour conclure le futur accord potentiel sur les entreprises et les droits de l'homme, et quelles approches sont envisageables pour l'UE de mettre en œuvre un tel accord dans son ordre juridique.

\section{Mots clés}

Droits de l'homme; Union Européenne; traité international; responsabilité sociale des entreprises; due diligence. 


\section{CONTENTS}

I. INTRODUCTION. II. LEGALLY BINDING INSTRUMENT ON BUSINESS AND HUMAN RIGHTS AS A CHALLENGE FOR INTERNATIONAL COMMUNITY AND THE UNITED NATIONS: 1. Calling for corporate responsibility for human rights violations. 2. From Draft Code of Conduct for Transnational Corporations to UN Norms on the responsibilities of transnational corporations and other business enterprises with regard to human rights 3 . From UN Guiding Principles on Business and Human Rights to Zero Draft and to the Third Revised Draft. III. EU AS AN ACTOR IN AREA OF BUSINESS AND HUMAN RIGHTS: 1. Legal framework for EU's external engagement in business and human rights. 2. The EU and binding instrument on business and human rights. IV. EU AND COMPETENCE TO CONCLUDE INTERNATIONAL AGREEMENT ON HUMAN RIGHTS: 1. General remarks. 2. Expressed external competence and human rights. 3. Implied external competence and human rights. 4. Competence of the EU regarding the "Third Revised Draft". 5. Adoption by Directives. V. CONCLUSIONS. BIBLIOGRAFHY.

\section{INTRODUCTION}

Although not a novel theme, the relationship between business and human rights is still a current topic due to several ideological reasons. The primary rests in lack of efficiency of the current state-centred protection of human rights, particularly in areas where enforcement powers of local governments are limited, the government neglects human rights protection, or even violates human rights itself (Abe, 2016; Clapham, 2006, 2008; McCorquodale, 2003; McCorquodale and Simons, 2007; A. Nolan, 2009; J. Nolan, 2005b). Since this approach acknowledges real power of business corporations to influence observance of human rights or violate them without effective remedies, some authors consider transnational corporations subjects of international law much like states (Alvarez, 2011; Nowrot, 2011; Peters et al., 2009; Reinisch, 2005; Worster, 2016) . This concept is politically sensitive, showing the division of the world between industrialized and developing 
countries, coincidentally rich for natural resources, as well as exploited for their cheap workforce. Since most gross violations of human rights occurred in countries where subsidiaries of transnational companies exploited natural resources or human workforce, while parental companies were established in e.g. Europe, USA, Canada, or China, the source of tension is apparent.

Since 1970s, several lines of approaches and international fora have appeared: the United Nations (hereinafter "UN"), the International Labour Organization (International Labour Organization, 2017; Letnar Černič, 2009), the Organization for Economic Cooperation and Development (Jonge, 2011: 42), as well as national approaches (Colangelo, 2016; Deva, 2012; Enneking, 2014; Kolieb, 2013, 2014; Kontorovich, 2014; Marullo and Zamora Cabot, 2016; Mills, 2014; Skinner, 2014; Swaine, 2016) or approaches based on responsible investors and consumers and business self-regulation (Hazenberg, 2016: 494-495; Jonge, 2011: 26-55; Kinley and Tadaki, 2004: 953-956).

This paper will select only one of these efforts to attribute responsibility for protection of human rights within the ambit of the UN, namely the current discussion on UN binding instrument on business and human rights. The aim of this paper is to assess the position of the European Union (hereinafter "EU") in this development. For this purpose, it is necessary to sketch the progress on the topic in general (Section II). As a value-oriented entity, inevitably, the EU response to this development must be assessed in turn (Section III). Even though the EU has duty to engage in international relations to promote its values, the principle of conferral requires careful assessment of the competences of the EU in relation to international treaties dealing with business and human rights (Section IV). These issues became much more relevant due to recent engagement of the European Parliament that has called on the European Commission "to propose a negotiating mandate for the Union to constructively engage in the negotiation [...] to regulate, in international human rights law, the activities of transnational corporations and other businesses...". ${ }^{3}$ However, the European Parliament did not suggest any precise content of such an international agreement, and no specified legal basis, calling for analysis of these topics provided in this paper.

3 European Parliament resolution of 10 March 2021 with recommendations to the Commission on corporate due diligence and corporate accountability (2020/2129(INL)), paragraph 30, https://bit.ly/3m76VZH. 


\section{LEGALLY BINDING INSTRUMENT ON BUSINESS AND HUMAN RIGHTS AS A CHALLENGE FOR INTERNATIONAL COMMUNITY AND THE UNITED NATIONS}

\section{CALLING FOR CORPORATE RESPONSIBILITY FOR HUMAN RIGHTS VIOLATIONS}

The impact of business on human rights, and gravity of violations thereof that are attributable to corporations is one of the most visible, yet also most contentious issue nowadays. Intense scrutiny of business enterprises and their obligations regarding fundamental human rights is ongoing, stirred up regularly by various allegations of corporate misconduct, such as social media companies' pursuit of profit over privacy (Klein, 2016: 18), or their inaction in combatting hate crimes, or even incitement to genocide (Irving, 2019). Implications corporate acts and omissions may have on human rights are firmly established nowadays. Case in point are corporate activities of multinational enterprises in a globalized world, especially considering the situation of poor communities throughout the developing world affected by entities of which "the overwhelming majority are based in the advanced economies of developed countries" (Ji, 2015: 401). These were involved in violations of a plethora of human rights of the poor communities in developing countries, including clean environment, freedom of expression, fair trial, freedom from ill-treatment, or even right to life (cf. Adeyeye, 2007; Grear and Weston, 2015). Moreover, contemporary research shows not only those corporations negatively affect enjoyment of human rights, but also that often, corporate human rights violations are perpetrated through direct participation or support, not acceptance, negligence, or omission. All too often, subsidiaries of transnational companies also exploited natural resources or human workforce, while parental companies were established in rich, industrialized countries across the globe, distancing themselves from the abuses they did not want to be associated with (cf. Adeyeye, 2007; Clough, 2008; Kaleck and Saage-Maaß, 2010; Kolieb, 2014). Finally, we currently also face expansion of security and military services provided by private actors that develop necessity of re-designing humanitarian law (e.g. Cameron, 2006; Gillard, 2006; Milliard, 2003; Percy, 2012; Scheimer, 2009; Slim, 2012; Wennmann, 2012; White, 2016).

From the legal point of view, there are several options of international approach to business and human rights. Bilchitz advanced several rationales in support of an international legally binding instrument, including its binding force itself, clarification of legal norms, or creating access to remedies and accountability (2016). Soft-law solutions or a new lex mercatoria allow 
corporations themselves to be involved in creation and shaping of regime of corporate and their voluntary commitment can be an appreciable path (Pariotti, 2009: 152).

The UN has been active in both approaches presented throughout the historical development: hard law - represented currently by the Zero Draft of Legally Binding Instrument to Regulate, in International Human Rights Law, the Activities of Transnational Corporations and Other Business Enterprises (hereinafter "Zero Draft") and its three revisions, and soft law - represented by the Global Compact of 2000 and United Nations Guiding Principles on Business and Human Rights (hereinafter "UNGPs"). ${ }^{4}$

The Global Compact introduced by the UN Secretary General is distinct from other initiatives within the auspices of the UN regarding human rights and business considered below, since it merely enumerates ten fundamental principles that companies should follow voluntarily and adopt a principles-based approach towards their basic responsibilities (Leisinger, 2017: 118-119). Failure to cooperate with the Global Compact could potentially lead to removal of the business from list of participants therewith. ${ }^{5}$ Contrary to objection of states to treaty-like efforts, the position of enterprises has been mostly positive, especially when they already satisfied the standards set forth without incurring additional costs (Janney et al., 2009: 418). Indeed, he broad wording and unprecise content of duties of business are other sources of criticism of the Global Compact (J. Nolan, 2005a: 461-462) and flexible threshold for fulfilment of requirements laid down by the Global Compact may lead to "blue-washing", i.e. purely formal adherence to the Global Compact (Grear and Weston, 2015: 39; King, 2001: 482).

\section{FROM DRAFT CODE OF CONDUCT FOR TRANSNATIONAL CORPORATIONS TO UN NORMS ON THE RESPONSIBILITIES OF TRANSNATIONAL CORPORATIONS AND OTHER BUSINESS ENTERPRISES WITH REGARD TO HUMAN RIGHTS}

Turning to the attempts at producing a binding framework for regulation, it is apparent that current considerations of business responsibilities in relation to human rights were subject to many twists throughout the past

4 Human Rights Council, 'Guiding Principles on Business and Human Rights: Implementing the United Nations "Protect, Respect and Remedy" Framework' Resolution A/HRC/17/31 (21 March 2011), paragraph 14.

5 United Nations Global Compact, 'Note on Integrity Measures', 2010 https://bit. ly/3lny61T accessed 23 May 2020. 
(Cf. Jerbi, 2009). The UN attempted to adopt regulation of business activities as a Code of Conduct, which was drafted in the Economic and Social Council (hereinafter "ECOSOC") on various occasions that eventually led to the 1990 Draft Code of Conduct for Transnational Corporations (hereinafter "1990 Draft Code of Conduct") that contemplated principles on business conduct respecting sovereignty of states, human rights, cultural traditions of host countries, avoiding corruption and many other obligations. ${ }^{6}$ The Code of Conduct was to be adopted by the UN General Assembly (hereinafter "UNGA"), however negotiations in the ECOSOC collapsed in the early 1990 s due to disagreements among developed and developing countries (Murphy, 2005; Rubin, 1995).

Even after failure of the 1990 Draft Code of Conduct, the UN nevertheless persisted in attempts to regulate business, albeit with a limited scope of human rights protection. The Sub-Commission on the Promotion and Protection of Human Rights adopted Norms on the responsibilities of transnational corporations and other business enterprises with regard to human rights (hereinafter "UN Norms") in 2003. ${ }^{7}$ UN Norms once again pushed for a mandatory framework, based on various treaties in force and international custom, in spite of the fact that Norms themselves were not drafted with the aspiration to take form of an international treaty (Weissbrodt and Kruger, 2003: 913-914). Although neither states nor corporations were ready to accept this approach at the time and consent to binding regulation, " $[t]$ hese objections [...] may be the result of the joining of various (over-) ambitious intentions in the Norms, and may not necessarily predict the failure of all future 'hard law' initiatives." (Miretski and Bachmann, 2012: 40).

The legal status and binding force of the UN Norms were however not the only points of contention. Additionally, the UN Norms were to be implemented by the business enterprises directly, while monitored by the $\mathrm{UN}$ and other international and national mechanisms. ${ }^{8}$ The language of the UN Norms introduced a legally binding document with non-voluntary

6 Economic and Social Council, 'Draft Code of Conduct on Transnational Corporations' Resolution E/1990/94 (12 June 1990).

7 Sub-Commission on the Promotion and Protection of Human Rights, 'Norms on the responsibilities of transnational corporations and other business enterprises with regard to human rights' Resolution E/CN.4/Sub.2/2003/12/Rev.2 (26 August 2003).

8 Sub-Commission on the Promotion and Protection of Human Rights, 'Norms on the responsibilities of transnational corporations and other business enterprises with regard to human rights' Resolution E/CN.4/Sub.2/2003/12/Rev.2 (26 August 2003), 6, at paragraph 16 . 
participation of corporations, which were regarded as primary duty-bearers (Kinley and Chambers, 2006: 452), as well as enforcement mechanism. This led to the UN Norms being opposed by states and businesses alike (Alston, 2005: 14; Jonge, 2011:36, 39; Ruggie, 2007: 826; Vazquez, 2005: 929). Eventually, it brought about the demise of the project, abandoned by the UN Commission on Human Rights, which refused to grant the UN Norms any legal standing, ${ }^{9}$ with the blame being placed on undermining the status of states in international law and progressive creation of novel international law norms (Miretski and Bachmann, 2012: 8-10; Ruggie, 2007: 825-826).

\section{FROM UN GUIDING PRINCIPLES ON BUSINESS AND HUMAN RIGHTS TO ZERO DRAFT AND TO THE THIRD REVISED DRAFT}

The considerations of international implementation mechanism with authority over businesses independent of states proved to be detrimental also to interests of governments hosting such companies. In fact, corporate actions could thereafter be labelled illegal, violating legal obligations, instead of merely contravening set of voluntary standards. Such possibility, it is argued, discouraged states from pushing forward such agenda, where it would damage preferences of corporations domiciled in their territory (Ruggie, 2007: 822).

With the UN Norms project failing to gain support, the first international standards pertinent to the interplay of business and human rights that received the endorsement from international community were the UNGPs, adopted by the UN Human Rights Council (hereinafter "HRC"). ${ }^{10}$ With this endorsement, the abovementioned paradigm shift became firmly settled in further attempts to regulate business-related aspects of human rights protection, distinguishing between duties to respect, protect, and fulfil, and the distinction between respective duty-holders. Additionally, the HRC established the Working Group on the issue of human rights and transnational corporations and other business enterprises (hereinafter "UN WG"), as well as Forum on Business and Human Rights under guidance of the UN WG, to

9 Commission on Human Rights, 'Responsibilities of transnational corporations and related business enterprises with regard to human rights' Decision E/CN.4/ DEC/2004/116 (22 April 2004).

10 Human Rights Council, 'Human rights and transnational corporations and other business enterprises' Resolution A/HRC/RES/17/4 (6 July 2011). 
support the implementation of UNGPs. In 2011, its mandate was to run for three years, but was extended in $2014,{ }^{11} 2017,{ }^{12}$ and $2020 .{ }^{13}$

Dichotomy between duty to protect/duty to respect allowed general feasibility and acceptability of the UNGPs. This dichotomy stems from the concept that corporations, unlike states, do not have duty to protect human rights, merely a responsibility (in other words, an imperfect duty) to do so "all things considered, where exceptions are permissible" (Werhane, 2016: 8). Such distinction presupposes that obligations of business entities do not entail a duty of protecting human rights, only a duty of respect for them, giving more discretion for corporate action (cf. Werhane, 2016; Wettstein, 2015). Thus, the duty of respect, which entails refraining from infringing human rights, is incumbent on business and states alike, ${ }^{14}$ while the duty to protect is not placed on business. ${ }^{15}$ In part, this lesser scope of business obligations arises from the fact that obligation to protect requires its bearers to prevent third parties from interfering with human rights. ${ }^{16}$ Adequate discharge of such obligation requires presence of a scheme for regulating conduct of third parties and securing compliance, which traditionally assumes state action, through legislative and executive powers. The corporations, it is suggested, would therefore satisfy their human rights obligations simply by considering

11 Human Rights Council, 'Human rights and transnational corporations and other business enterprises' Resolution A/HRC/RES/26/22 (15 July 2014).

12 Human Rights Council, 'Business and human rights: mandate of the Working Group on the issue of human rights and transnational corporations and other business enterprises' Resolution A/HRC/RES/35/7 (14 July 2017).

13 Human Rights Council, 'Business and human rights: mandate of the Working Group on the issue of human rights and transnational corporations and other business enterprises, and improving accountability and access to remedy' Resolution A/HRC/ RES/44/15 (23 July 2020).

14 Human Rights Council, 'Guiding Principles on Business and Human Rights: Implementing the United Nations "Protect, Respect and Remedy” Framework' Resolution A/HRC/17/31 (21 March 2011: paragraph 13).

15 Cf. Human Rights Council, 'Guiding Principles on Business and Human Rights: Implementing the United Nations "Protect, Respect and Remedy” Framework' Resolution A/HRC/17/31 (21 March 2011), paragraph 6 as regards the state-centric approach towards duty to protect, which does not contemplate implications of such duty on business enterprises.

16 Committee on Economic, Social and Cultural Rights, 'General Comment No. 15 (2002) The right to water (arts. 11 and 12 of the International Covenant on Economic, Social and Cultural Rights)' Resolution E/C.12/2002/11 (20 January 2003), paragraph 23 . 
their conduct under applicable governing law, as they would in fact gain too much power protecting human rights proactively (Bishop, 2012: 141-142).

At the same time, desire to create a legally binding instrument persisted at the UN level, and parallel to the UN WG, the HRC created an open-ended intergovernmental working group on transnational corporations and other business enterprises with respect to human rights, tasked with elaborating on yet another binding instrument dealing with the matter. The creation of a second specialized body was however far from consensual, where simple majority in the UN HRC voting in support of the proposal consisted merely of 20 members. Another 13 members abstained and 14 voted against the resolution. ${ }^{17}$ The Zero Draft sought to regulate various legal aspects of human rights violations in the context of business activities of a transnational character. Apart from liability of business for human rights abuses, it therefore regulates also issues related to jurisdiction, conflict of laws, or rights of victims. Consistently with other human rights treaties, the Zero Draft intended to create a committee tasked with overseeing implementation of the instrument, as well as adoption of general comments, or concluding observations on periodic reports of prospective states parties. ${ }^{18}$

The Zero Draft was revised ${ }^{19}$ by the open-ended working group during its fifth session, where it was proposed to expand the scope of drafted binding legal instrument to include not only transnational corporations and enterprises with transnational character of operational activities, but also to any local business registered under domestic law. While certain part of the open-ended working group considered such progress incompatible with mandate established by the Human Rights Council, most delegations

17 Human Rights Council 'Elaboration of an international legally binding instrument on transnational corporations and other business enterprises with respect to human rights' Resolution A/HRC/RES/26/9 (14 July 2014).

18 Open-ended intergovernmental working group on transnational corporations and other business enterprises with respect to human rights, 'Legally Binding Instrument to Regulate, in International Human Rights Law, the Activities of Transnational Corporations and Other Business Enterprises. Zero Draft' 16 July 2018, https://bit. ly/3prrLVJ, accessed 24 May 2020.

19 Open-ended intergovernmental working group on transnational corporations and other business enterprises with respect to human rights, 'Legally Binding Instrument to Regulate, in International Human Rights Law, the Activities of Transnational Corporations and Other Business Enterprises. Revised Draft' (16 July 2019), https://bit. ly/3po8dBu, accessed 24 May 2020 (hereinafter "Revised Draft"). 
welcomed such expanded scope,$^{20}$ indicating potential for further clashes within the UN. Potentially, the conceptual clashes may form reason for other states to follow suit in US withdrawal from the HRC in 2018. While in that case, the reason was alleged bias against certain states and political interests of the US ('United States Withdraws from the UN Human Rights Council, Shortly After Receiving Criticism About Its Border Policy', 2018), the US similarly continued to oppose business and human rights treaty process. ${ }^{21}$

Geographical, as well as political divisions on the issue of business and human rights therefore persist, with notably all of the EU Member States present in the HRC voting against Resolution 26/9, establishing the open-ended working group (e.g. Ruiz Galán, 2016). The concord between industrialized countries and less developed countries is nevertheless crucial for the success of the project (Aaronson, 2009; Adeyeye, 2007; Clough, 2008; Kaleck and Saage-Maaß, 2010; Kelly, 2016; Kolieb, 2014). Without genuine common understanding of developed and developing countries, the activities within the UN HRC remain smoke and mirrors that simulate efforts to create legally binding international instrument on business and human rights.

The Second Revised Draft, presented in $2020,{ }^{22}$ went further in clarification of concepts and the scope of the legally binding instrument. Comparing to the Zero Draft, that referred to "all international human rights and those rights recognized under domestic law", the scope of the Second Revised Draft was carved more precisely to "all internationally recognized human rights and fundamental freedoms emanating from the Universal Declaration of Human Rights, any core international human rights treaty and fundamental ILO convention to which a state is a party, and customary international law." (Art. 3). The Second Revised Draft also incorporated understanding of UNGPs regarding business and human rights changing the first limb of its purpose to "to clarify and facilitate effective implementation of the obligation of States to respect, protect and promote human rights in the context of business activities, as well as the responsibilities of business enterprises in this regard" (Art. 2

20 Human Rights Council 'Report on the fifth session of the open-ended intergovernmental working group on transnational corporations and other business enterprises with respect to human rights' Resolution A/HRC/43/55 (9 January 2020) p. 5.

21 US Mission to International Organizations in Geneva, 'U.S. Government's Opposition to the Business and Human Rights Treaty Process' (26 October 2020).

22 Open-ended intergovernmental working group on transnational corporations and other business enterprises with respect to human rights, 'Legally Binding Instrument to Regulate, in International Human Rights Law, the Activities of Transnational Corporations and Other Business Enterprises. Revised Draft' (6 August 2020) https://bit. ly/3psKQa4, accessed 11 July 2021 (hereinafter "Second Revised Draft"). 
par. a). ${ }^{23}$ Hence, in this context, the wording of the draft changed as well: it refers to "abuse" of human rights, rather than "violation" of human rights when referring to business entities. Thus, the Second Revised Draft started to resemble more the concept of division of duties and responsibilities introduced by the UNGPs than the ambiguous and unbalanced wording of the Zero Draft.

Concerning the most recent Third Revised Draft from 2021, ${ }^{24}$ the wording simplified certain concepts, while expanding some of the definitions at the same time, such as victim's definition now not listing examples of harm and removing persons assisting to victims from the scope of victimhood as well. Family members are also no longer mandatorily considered victims, giving leeway to state implementation. On the other hand, a detailed enumeration, albeit non-exhaustive, of business activities was provided, which may draw allegations of overly detailing terms that may stir further controversy. The scope of draft also covers business "activities" instead of enterprises (Art. 3), which seems yet again an attempt to expand scope to cover even entities not strictly designated as enterprises, however with unclear and vague wording. Diplomatic and consular assistance for victims was also removed from the draft (Art. 4), even though the practical reality of such assistance is unlikely to be affected by the instrument. In remedying human rights abuses, the draft now incorporates explicit recognition of hardships women, vulnerable groups, children, older persons and other groups face when seeking redress (Arts. 7, 15 and 16), and importantly, the draft no longer requires recognition of criminal liability for legal persons (Art. 8). At the same time, broadening possible jurisdictional grounds through the effects doctrine and state of nationality or domicile of the victim (Art. 9) can yet again undermine trust of developed countries in the instrument, where they may be doubtful of judicial proceedings in developing states. In sum, it is apparent that the draft yet again aims to please everyone, at the cost of creating a scheme that falls foul of expectations of developing states, but still becomes too controversial in the eyes of industrialized world to warrant participation.

23 Comparing to corresponding provision of the Zero Draft: "To strengthen the respect, promotion, protection and fulfilment of human rights in the context of business activities of transnational character."

24 Open-ended intergovernmental working group on transnational corporations and other business enterprises with respect to human rights, 'Legally Binding Instrument to Regulate, in International Human Rights Law, the Activities of Transnational Corporations and Other Business Enterprises. Third Revised Draft' (17 August 2021) https://bit.ly/2XzfH9a, accessed 27 September 2021 (hereinafter "Third Revised Draft"). 


\section{EU AS AN ACTOR IN AREA OF BUSINESS AND HUMAN RIGHTS}

\section{LEGAL FRAMEWORK FOR EU'S EXTERNAL ENGAGEMENT IN BUSINESS AND HUMAN RIGHTS}

The Treaty of Lisbon established an explicit external value-oriented framework, including protection of human rights, based particularly on Arts. 3, 6, and 21 TEU, allowing the EU to build its role as the human rights defender and human rights promoter beyond its borders (Mokrá and Janková, 2018: 93). Such framework was preceded by a process that recognized human rights under EU law by the Court of Justice of the European Union (hereinafter "CJ EU"), firstly as general principles, later through adoption of Charter of Fundamental Rights of the EU (hereinafter "Charter") as a non-binding human rights catalogue, to its binding effect strengthening its place within primary EU law (Douglas-Scott, 2011: 649). Similarly, the human-rights-oriented EU law approach is present in the calls for EU accession to the European Convention on Human Rights (hereinafter "ECHR"), which were incorporated into what is now Art. 6(2) TEU, although such proposals were present long before the Lisbon Treaty (Lysina, 2018: 60).

It must be noted that the EU's catalogue of human rights provided by the Charter can be seen as more far reaching than Universal Declaration of Human Rights (hereinafter "UDHR") and UN core human rights treaties. Although we have to be aware, that "the multi-layered environment limits the adoption of the fundamental document in the Union connected to human rights" (Mokrá and Janková, 2018: 58) due existing obligations of EU members stats to UN human rights treaties. The EU Agency for Fundamental Rights itself supports such approach, viewing other international instruments as "minimum standards" or "sources of interpretation". ${ }^{25}$ Nevertheless, it recognizes the necessary overlap of the Charter with existing international human rights treaties, but maintains the position that certain Charter provisions are not mere reflection of existing UN instruments, but their elaboration or extension. ${ }^{26}$ Notwithstanding the content of rights enshrined in the Charter,

25 European Union Agency for Fundamental Rights, Applying the Charter of Fundamental Rights of the European Union in law and policymaking at national level. Guidance (Publications Office of the European Union 2018) p. 23.

26 The FRA, overviewing the core UN international human rights treaties, found that unlike the Charter, UN instruments do not explicitly recognize e.g., protection of personal data and its safeguards, protection of conscientious objection, freedom of arts and sciences, freedom to work and conduct business, prohibition of discrimination of third country nationals authorized to work, or right to good administration 
its "operative" scope is limited by Art. 51 thereof, i.e. operates within the powers of the Union and respective powers of EU institutions [Art. 51(1)] and application of the Charter cannot expand or modify powers and tasks of the EU [Art. 51(2)]. Hence, the catalogue of rights declared by the Charter can be more far reaching and more comprehensive than previous instruments regarding the list and wording of the provision of the Charter itself (Ciacchi, 2019; Sever, 2014).

Notwithstanding the limited scope of "novelties" introduced by the Charter, the understanding and application of human rights in the EU context can be, on the one side, subject to "cultural relativism" that diminishes their universality, on the other side, this concept is also expanded by various politicians and interest groups to other areas when defining more and more individual rights as human rights and thus inflating this concept (Grear, 2007; Kerikmäe and Nyman-Metcalf, 2018). This is also related with the concept of "EU identity and the fact, that human rights were conceived of as values stated in Article 2 TEU" (Mokrá, 2021: 60).

Moreover, the content and extent of the human rights is not even consistent across the EU, and several areas left for assessment by the Members States cause discord even between Member States (Stehlík, 2019). Although the Treaties established common quasi-constitutional framework, it is still based on common constitutional heritage of the Member States respecting their national identity (Schroeder, 2016). All these factors jointly pose a risk for position of the EU and its Member States, making it significantly harder to determine the extent to which they should push for inclusion of Charterbased rights into the prepared international treaty on business and human rights. Without trying to define, in this place, the content of universal rights feasible for an international treaty on human rights and business, it is nevertheless apparent that even the EU is not completely unified regarding all human-right concepts, while sharing the value of high protection of human rights in international relations.

Hence, international instrument on business and human rights will not be merely "another human rights catalogue" along the Charter, but a brand-new legal device with completely different legal context and power. Several observations must be made concerning the relationship between the Charter and the international instrument on business and

and access to documents. Cf. European Union Agency for Fundamental Rights, $A p$ plying the Charter of Fundamental Rights of the European Union in law and policymaking at national level. Guidance (Publications Office of the European Union 2018), pp. 82-92. 
human rights, if adopted by the EU. First, adoption of such international instrument must be within the competence of the EU and in accordance with the primary law, including the Charter. Secondly, the Charter cannot expand the scope of the competence of the EU and create additional tasks; however, the international instrument on business and human rights might create such tasks and new rules within the scope of EU competence. The CJ EU analysed international agreements case-by-case and although in general it accepted direct effect of international agreements (Stoynov, 2017: 49-52), some agreements, such as the Agreement Establishing the World Trade Organization, were deprived of such effect (Fabri, 2014; Jeney, 2015). The direct effect of international agreements is based of several criteria developed by the CJ EU (Stoynov, 2017: 52-55) that are linked to the content of agreements and enforcement mechanisms on international as well as national level. Whether the eventual instrument on business and human rights will possess such direct effect is hard to predict, given the current stage of negotiations.

Concerning the area of business and human rights specifically, the $\mathrm{EU}$ is obliged to promote multilateral solutions on an international scene by virtue of Art. 21(1) of the Treaty on European Union and must pay a special attention on the UN framework in this regard, as required by the TEU (Addo, 2014: 141). Given the fact that UNGPs were the only instrument adopted so far by the international community as a whole, it seems natural that within European legal framework, similar consensus was reached and resulted in adoption of hard-law, as well as soft-law measures. Thus far, the EU seems to be able to observe its obligations to promote multilateral solutions, especially within the UN system and sustain "the ambition to become more visible in the international area, even to become recognized as an international actor rather than not only regional actor" (Mokrá, 2020: 178).

Currently, the clauses on protection of human rights became a regular provision of international trade agreements "injecting a social dimension into EU's trade policy” (Borlini, 2018: 80-82). This situation creates an interesting paradox: in the area of human rights, the EU is not legally bound by any international treaty on human rights (except the Convention on the Rights of Persons with Disabilities), but it is bound by a multitude of human rights clauses included in its more than 120 trade treaties (Bartels, 2014: 1079). Being still in its ambit of its exclusive competence of common commercial policy (or development policy) (Jacur, 2018: 470), the EU can pursue its human rights agenda, including corporate social responsibility. 
The EU Global Human Rights Sanction Regime ${ }^{27}$ allows, inter alia, the EU actions against non-state actors due to serious violations of human rights. The EU considers not only violation of those rights included in the provisions of these acts, but also rights within the scope of non-exhaustive list of international instruments, as well as customary international law. Thus, the EU engages enforcement of human rights treaties even when it is not a party to such treaties.

\section{THE EU AND BINDING INSTRUMENT ON BUSINESS AND HUMAN RIGHTS}

Since the EU's policy on business and human rights integrates "general" human rights policy and corporate social responsibility regulations (CSR), this second limb can be traced back to the Commission of Jacques Delors that understood CSR "as a tool to regulate capitalism and to counter the liberal single market programme" (Drahn, 2020: 18, 29). In 2021, the Commission presented Green Paper on CSR that envisaged role of the EU in "providing an overall European framework, aiming at promoting quality and coherence of corporate social responsibility practices, through developing broad principles, approaches and tools, and promoting best practice and innovative ideas" and supporting best practices (par. 18). ${ }^{28}$ The EU endorsed process leading to the UNGPs and the Council in its conclusions in 2009 "gave emphasis to the important role of business in achieving full respect for human rights. ${ }^{29}$ Drahn notes that the activity of the EU on the field of CSR did not have constant pace and following the initial enthusiasm after publication of the Green Paper, it loosened around 2005-2006 to avoid unnecessary burden on business and it turned back to intensifying the regulation after the EU's financial crisis (2020). The regulatory approach pursued by the Commission was not welcomed by business stakeholders that saw CSR as voluntary process designed by business community (De Schutter, 2008: 235-236).

27 Council Decision (CFSP) 2020/1999 of 7 December 2020 concerning restrictive measures against serious human rights violations and abuses (OJ L 410 I, 7.12.2020, p. 13-19), Council Regulation (EU) 2020/1998 of 7 December 2020 concerning restrictive measures against serious human rights violations and abuses (OJ L 410 I, 7 December 2020, pp. 1-12).

28 Green paper - Promoting a European framework for corporate social responsibility, COM/2001/0366 final.

29 Paragraph 17 of the Council Conclusions on Human Rights and Democratisation in third countries. 2985th Foreign Affairs Council meeting. Brussels, 8 December 2009. 
The approach of the EU to implementation of the UNGPs has been combining binding sectoral and regulatory frameworks and soft law political endorsement and support of UNGPs. The Communication of the Commission on CSR in 2011,30 inter alia, expected all European enterprises to meet the corporate responsibility to respect human rights, as defined in the UNGPs and invited the EU Member States to develop national plans for the implementation of the UNGPs by the end of 2012..$^{31}$ These "commitments" have appeared to be mostly rhetorical without visible practice (Letnar Černič, 2018: 238), even though they were supported by later declarations. In fact, in January 2013, only 19 EU Member States reported that they launched or progressed in preparation of the national action plans (Addo, 2014: 141) ${ }^{32} \mathrm{In}$ measures oriented to business, the EU continued with mix of issuing sectoral guidance (Addo, 2014: 141), as well as integrating elements of CSR in its legislation in the field of accounting, public procurement, labour rights of third-country nationals, human trafficking, cooperation in matters of civil, and criminal judicial cooperation (Drahn, 2020). This fragmented legislative framework of implementation of UNGPs by the EU is at least summarized in the Commission Staff working document of 2015. ${ }^{33}$

Thus, there is an impetus to find common ground in proposals combining mandatory and voluntary instruments into a so-called "smart mix" of measures, both national and international (UN Working Group on Business and Human Rights, 2016: 13), which could require certain minimal standards while rewarding corporations that go beyond compliance in human rights standards (Government of Finland, 2019: 8). This approach seems to contemplate ways of securing best of both worlds, yet the concept presented during presidency of Finland to the Council of the EU in 2019 does little to outline precise distinction between instruments that should be established as binding, and which should merely complement them. While the idea itself presents essential concepts, such

30 Communication from the Commission to the European Parliament, the Council, the European Economic and Social Committee and the Committee of the Regions. A renewed EU strategy 2011-14 for Corporate Social Responsibility /* COM/2011/0681 final */ (hereinafter "CSR Communication 2011”).

31 CSR Communication 2011, p. 14.

32 Currently only 15 EU Member States launched actually their National Action Plan and 3 Member States committed themselves to prepare such plans.

See https://bit.ly/3b2tNTO, (accessed 1 October 2021).

33 European Commission. Commission Staff Working Document on Implementing the UN Guiding Principles on Business and Human Rights - State of Play, SWD(2015) 144 final, Brussels, 14 July 2015. 
as mainstreaming social standards in public procurement procedures (Government of Finland, 2019), the line between mandatory and voluntary instruments is almost certain to prove a contested point, just like the nature of measures developed within the UN. Such risks are clearly manifest in other perspectives from the Finnish presidency that maintain a clear and strict distinction between state responsibility to protect and corporate responsibility to respect human rights (Government of Finland, 2019) The Finnish presidency thus continued on the path of the group of EU actors ${ }^{34}$ that have not shied away from calling voluntary instruments ineffective and insufficient outright and called on the EU to adopt binding legislation on human rights due diligence (Government of Finland, 2019), as the mix of mandatory and voluntary requirements is imbalanced in favour of the latter (Augenstein et al., 2017: 10). This is corroborated by existing research which found that many avenues of binding regulation, which could more effectively address systematic deficiencies, was often lacking in national action plans (International Corporate Accountability Roundtable and European Coalition for Corporate Justice, 2014: 4). The pessimistic approach towards predominantly voluntary instruments was also underlined by the European Parliament (hereinafter "EP") itself, openly calling voluntary adherence of corporations ineffective and additionally pointing out that it places such enterprises at a competitive disadvantage compared to those that choose to ignore the standards in their corporate social responsibility. ${ }^{35}$

The EU itself therefore firmly stands behind the extended scope of the binding instrument so far, covering any corporations instead of merely transnational ones, although limiting the content as based upon UNGPs (Zamfir,

34 The "Green Card" initiative by Parliaments of Estonia, Lithuania, Slovakia and Portugal, the UK House of Lords, the House of Representatives of the Netherlands, the Senate of the Republic in Italy, and the National Assembly of France in 2016 requested the European Commission for a legislative action to submit an ambitious legislative proposal implementing corporate social responsibility principles at European level. The European Commission in its response named its current activities in the field of corporate social responsibility and human rights due diligence, considering them sufficient. See European Commission, [2016], COM(2016) 5897 final, https:// bit.ly/3vNICmR; European Commission, Report from the Commission. Annual Report 2016 on Relations Between the European Commission and National Parliaments [2017], COM/2017/0601 final. https://bit.ly/2ZeGhor.

35 European Parliament 'European Parliament resolution of 4 October 2018 on the EU's input to a UN Binding Instrument on transnational corporations and other business enterprises with transnational characteristics with respect to human rights' Resolution 2018/2763/(RSP) (4 October 2018). 
2018: 7, 10). The EP specifically called upon both the EU and Member States to engage in negotiations concerning the UN binding treaty. ${ }^{36}$ Nevertheless, the EP also recognized the value of existing agreed international standards and called for implementation of the UNGPs. ${ }^{37}$

Additionally, there is a growing impetus arguing that the EU, among other actors, should utilize its power in international relations to enforce human rights standards in relation to their trading partners. ${ }^{38}$ Such practice would lead to a race to the top in terms of the UNGPs implementation. ${ }^{39}$ More recently, the approach was supported even within the EU, with the European Economic and Social Committee arguing that since the US or China are not intensely involved in drafting of the binding instrument, the EU can promote its goals via access to the common market, even if other economic powerhouses do not ratify the eventual treaty. Using European rules, the EU could allegedly make foreign corporations liable for violations of such treaty, leading to increased standards of human rights protection worldwide, through EU external relations. ${ }^{40}$ The Council in its strategy on human rights for 2021 declared its devotion to the project of legally binding instrument on business and human rights? "The EU will also participate actively in the UN discussions on a legally binding instrument on business and human rights with the aim to promote an instrument that can effectively enhance the protection of

36 European Parliament 'European Parliament resolution of 25 October 2016 on corporate liability for serious human rights abuses in third countries' Resolution 2015/2315/ (INI) (25 October 2016); European Parliament 'European Parliament resolution of 14 December 2016 on the Annual Report on human rights and democracy in the world and the European Union's policy on the matter 2015' Resolution 2016/2219/ (INI) (14 December 2016).

37 European Parliament 'European Parliament resolution of 14 April 2016 on the private sector and development' Resolution 2015/2315/(INI) (25 October 2016).

38 Working Group on the issue of human rights and transnational corporations and other business enterprises 'The report of the Working Group on the issue of human rights and transnational corporations and other business enterprises' Resolution A/ HRC/38/48 (2 May 2018), p. 15.

39 Working Group on the issue of human rights and transnational corporations and other business enterprises 'The report of the Working Group on the issue of human rights and transnational corporations and other business enterprises' Resolution A/ HRC/38/48 (2 May 2018).

40 European Economic and Social Committee 'Opinion of the European Economic and Social Committee on Binding UN treaty on business and human rights (own-initiative opinion)' Opinion EESC 2019/01278 (24 January 2019). 
victims of business-related human rights violations and abuses and create a more global level playing field." ${ }^{41}$

Mandatory due diligence in supply chains, envisaged by Commissioner Didier Reynders (Reynders, 2020), based referring to Study on Due Diligence Requirements through the Supply Chains (Smit et al., 2020a), and its inclusion into EU recovery package can create both strong incentive and pressure for business for implementing human rights standards in their supply chains. Moreover, enforcement of due diligence requirements can undoubtedly create export of EU minimal standards to the third countries. By this comprehensive legislation, the $\mathrm{EU}$ can move from mere encouraging business compliance (Palombo, 2020: 60) to making business liable for some human rights abuses. Establishing binding due diligence duty may open path for victims of human rights abuses in the third countries not only to litigate abuses themselves but also failures of duty of due diligence. It must be noted that several European countries already established national due diligence legislation (Cavanna, 2019; Muchlinski, 2021; Palombo, 2019; Savourey and Brabant, 2021) and therefore question of application of the principle of subsidiarity will be inevitably raised. The Council supported the plan of the Commission to introduce legislative proposal on due diligence in supply chains, but also calls the Commission to table much more general "EU legal framework on sustainable corporate governance." ${ }^{42}$

Concerning the Zero Draft, the EP also requested the introduction of certain bold provisions that were not included in the already contentious document. For example, if desired corporate criminal liability to be recognized, ${ }^{43}$ although Art. 10(12) of the Zero Draft contemplated that even non-criminal liability of corporations may be sufficient and leaves upon potential state parties to decide best on their preferred system of corporate human rights liability modes. However, the position to recognize corporate criminal liability is unclear, and it cannot be discerned whether EP sought to make it a binding obligation of any state in future drafts, or is satisfied with current draft, recognizing corporate criminal liability, but not making it mandatory and leaving greater discretion for states. The Third Revised

41 Paragraph 14 of Council Conclusions on EU Priorities in UN Human Rights Fora in 2021. Brussels, 22 February 2021, 6326/21, https://bit.ly/3Anr15y (accessed 2 October 2021).

42 Ibid., paragraph 46.

43 European Parliament Resolution of 4 October 2018 on the EU's input to a UN Binding Instrument on transnational corporations and other business enterprises with transnational characteristics with respect to human rights, $n^{\circ} 2018 / 2763 /(R S P)$ (4 October 2018). 
Draft eventually left the question out of the wording altogether, suggesting the EU was not able push the issue forward. In the end, the fundamental question that must be assessed is whether, even should the international binding instrument on business and human rights be eventually adopted, and its content would be in line with objectives of the EU, can the EU in fact become party to such agreement, having regard to competences split between Member States and the EU.

The development of the legally binding instruments on business and human rights within the legal framework of the EU moved forward by the resolution of the EP of 10 March $2021^{44}$ that recommended to the Commission to adopt two crucial legal instruments:

a) "to propose a negotiating mandate for the Union to constructively engage in the negotiation of a UN international legally binding instrument to regulate, in international human rights law, the activities of transnational corporations and other businesses;"

b) to "submit without undue delay a legislative proposal on mandatory supply chain due diligence, following the recommendations set out in the Annex hereto; considers that, without prejudice to detailed aspects of the future legislative proposal, Articles 50, 83(2) and 114 TFEU should be chosen as legal bases for the proposal".

The EP suggested the text of the proposal of the "Directive of the European Parliament and of the Council on Corporate Due Diligence and Corporate Accountability" (hereinafter "Draft Due Diligence Directive") in the Annex to this resolution, which does not cover only protection of human rights but also respect to the environment and good governance.

The Member States should establish three pillars of due diligence to be established by undertakings: due diligence strategy (Art. 4 to 8 ), grievance mechanism (Art. 9) and extra-judicial remedies (Art. 10). The Draft Due Diligence Directive incorporates international non-binding instruments and therefore establish them as a binding source of law within the territory of the EU, in particular:

a) Principle 17 of the UNGPs shall be a base of the prioritization strategy required by Art. 4(2)(iv) as a part of the due diligence strategy;

b) Principle 31 of the UNGPs and the United Nations Committee on the Rights of the Child General Comment No 16 shall provide criteria for the effectiveness criteria for non-judicial grievance mechanisms under Art. 9(2);

44 European Parliament Resolution of 10 March 2021 with recommendations to the Commission on corporate due diligence and corporate accountability (2020/2129(INL). 
c) the UNGPs, the ILO Tripartite Declaration of Principles concerning Multinational Enterprises and Social Policy, the OECD Due Diligence Guidance for Responsible Business Conduct, the OECD Guidelines for Multinational Enterprises, the OECD Guidance for Responsible Mineral Supply Chains, the OECD Due Diligence Guidance for Responsible Supply Chains in the Garment and Footwear sector, the OECD guidance for Responsible Business Conduct for Institutional Investors, the OECD Due Diligence for Responsible Corporate Lending and Securities Underwriting and the OECD-FAO Guidance for Responsible Agricultural Supply Chains, the United Nations Committee on the Rights of the Child General Comment 16 on State obligations regarding the impact of the business sector on children's rights and the UNICEF Children's Rights and Business Principles shall be duly considered by the European Commission when preparing non-binding due diligence guidelines under Art. 14.

Summing up, current momentum for introduction of binding measures on business and human rights is strong (Bright et al, 2020: 688) and stakeholder surveys showed that there are there is dissatisfaction with the existing legal landscape regarding their human rights due diligence obligations and business is aware of necessity of introduction of legislation on EU-level that will overcome deficiencies as well as fragmentation and thus can be in the interest of the business (Smit et al., 2020b: 269). However, introduction of EU legislation on business and human rights, even if it is incorporating UNGPs, is still internal action of the EU and its members and does not mean unconditional possibility of accession of international instrument on business and human rights. Similarly, support of negotiation and drafting treaty on business rights, declared by the EU's institutions, does not mean automatic political and legal feasibility of accession to such a treaty.

\section{EU AND COMPETENCE TO CONCLUDE INTERNATIONAL AGREEMENT ON HUMAN RIGHTS}

\section{GENERAL REMARKS}

There is no doubt that the EU can (and shall) include value-oriented requirements in all its external actions within its policies other than pure protection of human rights, e.g. common commercial policy, association and accession process (Müller-Graff, 2017). When including values and human rights into international agreements, the EU usually "exports" its values (Herlin-Karnell, 2012; Horvathy, 2017), tries to "shape" the course of development of international law (Wessel, 2016), however in the case of 
international agreement on business and human rights, the EU appears to be in the position of "rule-taker", rather than "rule-maker". When searching for the reason behind, as well as a way out of this approach, one of the vital factors to be explored is the competence that the EU may utilize to pursue its goals. Without appropriate competence, it remains unlikely that the EU or its institutions could transcend from the former position into the latter, more proactive and demanding. The consideration of such competence is therefore a condition precedent to any further discussion of prospective success, of EU participation.

If conduct of the EU fits into the frame of non-binding negotiation, discussion fora or political declarations, institutions can easily rely on Art. 3(5) of the Treaty on the European Union ("TEU") together with Art. 2 TEU, i.e. promotion of the EU's values on international scale. Such activities do not interfere with sovereign rights of Member States due to lack of binding effect. Moreover, the institutions of the EU can claim that they exercise their duties in general, i.e. representing the EU in international relations (Cf. Jørgensen and Wessel, 2011). This framework therefore indicates EU adopted a firm value-oriented approach towards its conduct internationally, which supports the proactive position of the $\mathrm{EU}$ on issues of business and human rights. The caveat here is described above - non-binding character of any measures eventually adopted by the EU.

The situation is, obviously, completely different in the case of conclusion of international agreements of adoption of other international decisions and instruments of binding nature. The evaluation of the feasibility of accession by the EU to "UN Treaty on Business and Human Rights" can give an answer to question if the EU can support such a project merely politically or if it can transform it into legal instrument with binding effect overall the EU.

Indeed, the conferral principle under Art. 5(1) TEU is crucial for any activity and adoption of legal act of the EU. However, stepping into the field of international agreements, we face system of complex web of exclusive competence of the EU, exclusive competence of the Member states, shared competence, which encompasses groups of agreements concluded by the EU solely, "mixed" international agreements (concluded by the EU and the Member States as one of the parties to the agreement) and agreements that are concluded by the Member States cooperating under instructions by the EU on a basis of principle of loyalty. ${ }^{45}$ Moreover, division of competence and shared competence has substantial impact on legal responsibility vis-à-vis other subjects of international law and unclear division of competence can undermine the enforcement of

45 Cf. Judgment of 7 October 2014, Germany v Council, C-399/12, EU:C:2014:2258. 
the duties stemming from the agreement by third countries or their nationals (Brodská and Scheu, 2018: 159).

Art. 216 of the Treaty on the Functioning of the European Union (hereinafter "TFEU") is the focal point for assessment of the competence of the EU to conclude international agreements, providing four alternatives for legal sources of the competence:

(1) “...the Treaties so provide ..."

(2) "...where the conclusion of an agreement is necessary in order to achieve, within the framework of the Union's policies, one of the objectives referred to in the Treaties..."

(3) "...is provided for in a legally binding Union act..."

(4) "... is likely to affect common rules or alter their scope."

Existence of the competence itself is crucial, and only in case of existence of the competence it is relevant to discuss character of such competence (i.e. exclusive or shared competence) (Lysina, 2018: 51). The EU does not have the competence to conclude an international agreement as a whole and competence in certain part of the agreement at issue allows the EU to be at least party to a "mixed" agreement together with the Member States.

\section{EXPRESSED EXTERNAL COMPETENCE AND HUMAN RIGHTS}

The first alternative provides an "express" competence of the EU to conclude international agreement and it is possible to identify fourteen instances of explicit competences in the Treaties: European Convention of Human Rights (hereinafter "ECHR") [Art. 6(2) TEU]; neighbourhood policy [Art. 8(2) TEU; common foreign and security policy [Art. 37 TEU]; withdrawal from the EU [Art. $50 \mathrm{TEU}$ ]; readmission [Art. 79(3) TFEU]; cooperation in research, technological development and demonstration [Art. 186 TFEU]; environment [Art. 191(4) TFEU]; common commercial policy [Art. $207 \mathrm{TFU}$ ]; development cooperation [Art. 209(2) TFEU]; economic, financial and technical cooperation measures [Art. 212(3) TFEU]; humanitarian aid [Art. 214(4) TFEU]; association [Art. 217 TFEU]; and exchange-rate systems [Art. 219 TFEU].

There is no express external competence of the EU to conclude "general" international agreements on human rights other than ECHR under Art. 6(2) TEU. In this context, it must be noted that possible accession of the EU to the ECHR can change the position of the EU also in the field of business and human rights, since it can raise possibility of responsibility as a "home state" of transnational national corporations for their actions abroad (for this concept see e.g. Methven O’Brien, 2018). 
Other areas of express external competence provide very few for establishing express external competence for concluding international agreements regarding human rights and such link to express external competence may appear merely accidentally (e.g., if it covers area of environmental protection [Art. 191(4) TFEU], development cooperation [Art. 209(2) TFEU], or humanitarian aid [Art. 214(4) TFEU]). The Opinion regarding EU-Singapore Free Trade Agreement (hereinafter "EUSFTA") ${ }^{46}$ showed that EU institutions shall be very careful when defining content of the competence in external relations. The CJEU very carefully severed from the EUSFTA provisions that explicitly do not fall within the common commercial policy as defined in the TFEU. Moreover, relying on such "breadcrumbs" of competences can be easily challenged by invoking the principle of proportionality. Therefore, it can be concluded that there is no viable express external competence of the EU to conclude international agreement on business and human rights. Additionally, it must be recalled that objective of human rights protection in the EU policies is not always self-standing. With the EU bound equally by international law (either treaty or custom-based), the human rights protection aspirations of the EU arise in other fields, or concluding international treaties on the basis of other expressed competence (cf. Bartels, 2014: 177-180).

\section{IMPLIED EXTERNAL COMPETENCE AND HUMAN RIGHTS}

"Implied" external competence broadens sphere of external action of the EU on a basis of existence of internal competence. This approach was established in $E R T A$ case $^{47}$ and developed in further case law dealing with various areas of international instruments, e.g. Agreement establishing a European laying-up fund for inland waterway vessels, ${ }^{48}$ International Labour Organization, ${ }^{49}$ World Trade Organization, ${ }^{50}$ European Convention on Human Rights (hereinafter "ECHR"),

\footnotetext{
46 Opinion of 16 May 2017, 2/15, EU:C:2017:376.

47 Judgment of 31 March 1971, Commission v Council (ERTA), 22/70, EU:C:1971:32, paragraph 16.

48 Opinion of 26 April 1977, 1/76, EU:C:1977:63.

49 Opinion of 19 March 1993, 2/91, EU:C:1993:106.

50 Opinion of 15 November 1994, 1/94, EU:C:1994:384.

51 Opinion of 28 March 1996, 2/94, EU:C:1996:140.
} 
Open Skies, ${ }^{52}$ and Lugano Convention. ${ }^{53}$ The conclusion of international agreement, as described in Art. 216 TFEU, represents the recognition of such implied external competence (Krajewski, 2012: 299).

When utilizing implied external competences, four possible scenarios shall be examined for the possibility of the conclusion of international agreement on business and human rights: (1) competence stemming from objectives, values and principles of the EU, (2) "extension" of competences of the EU via "flexible" clause of the Treaties, i.e. Art. 114 and 352 TFEU, (3) implementation of value and human rights-oriented provisions and (4) "implied implied" competence relying on provision not overtly focused on human rights protection as a vehicle to protect human rights. The boundaries of these possibilities must be assessed through the prism of established case law, as outlined above.

Protection of human rights as one of the values of the EU is omnipresent in the legal framework of the EU overall, however its implementation by the institutions of the EU is still under the scrutiny of the conferral principle, and therefore competence of the EU shall be properly monitored (Herlin-Karnell, 2012). In the international sphere, objectives of the EU regarding values, including protection of human rights are "broader and bolder as compared to the internal competences" (Herlin-Karnell, 2011). Although Art. 216 TFEU confers competence on the $\mathrm{EU}$ to conclude international agreements to achieve "objectives referred to in the Treaties", the very provision itself restricts this competence to "the framework of the Union's policies". Thus, values are the EU's "constitutional compass" (Herlin-Karnell, 2011) for the implementation of its policies, including its activities in international relations and for shaping international legal order, rather than being "stand-alone" sources of the EU's competence themselves (Herlin-Karnell, 2011). Opinion of the CJ EU regarding accession to the ECHR stated clearly, that "No Treaty provision confers on the Community institutions any general power to enact rules on human rights or to conclude international conventions in this

52 Judgment of 5 November 2002, Commission $v$ Denmark, C-467/98, EU:C:2002:625; Judgment of 5 November 2002, Commission v Sweden, C-468/98, EU:C:2002:626; Judgment of 5 November 2002, Commission v Finland, C-469/98, EU:C:2002:627; Judgment of 5 November 2002; Commission v Belgium, C-471/98, EU:C:2002:628; Judgment of 5 November 2002, Commissionv Luxembourg, C-472/98, EU:C:2002:629; judgment of the Court of 5 November 2002,- Commission v Austria, C-475/98, EU:C:2002:630; Judgment of 5 November 2002, Commission v Germany, C-476/98, EU:C:2002:631.

53 Opinion of 7 February 2006, 1/03, EU:C:2006:81. 
field" ${ }^{54}$ Although the CJ EU saw the importance of values, including human rights, in the legal framework of the EC, it was not a sufficient basis for accession to purely human rights agreement with non-EU countries, neither on a basis of express external competence, nor on a basis of implied external competence. The Treaty of Lisbon changed nothing from the point of view of possibility to accede to international agreement (other than the ECHR), dealing purely with human rights (Nakanishi, 2018: 15). Conclusion of accession agreement to the ECHR is now an express competence, which was not questioned in subsequent opinion $2 / 13$, unlike the question of extending EU competences themselves through the accession, which became a contested topic (cf. Łazowski and Wessel, 2015). The CJ EU in Opinion 2/13 noted that the legal situation is different from that one referred in Opinion 2/94, since "the accession of the EU to the ECHR has, since the entry into force of the Treaty of Lisbon, had a specific legal basis in the form of Article 6 TEU." 55 Therefore, non-existence of an express general competence to conclude international agreement on human rights, as explained in Opinion 2/94, remained uncontested and Art. 6(2) is a specific exemption from this rule.

In the case of non-existence of express competence of the EU (internal or external), it can be tempting to use "flexibility" clause of Art. 352 TFEU. The extension of the powers of the EU via Art. 352 TFEU is however limited by the wording of the provision itself - (1) it must be necessary, (2) it must be aimed to attaining objectives set out in Treaties, and (3) the extension shall be within "the framework of the policies defined in the Treaties". It appears that attaining the objectives of the EU cannot be sole legal basis of the application of the Art. 352 TFEU and the area of application shall be also covered by "policies" defined in the Treaties. Moreover, the realm of application of this provision was also restricted by declaration annexed to the TFEU: objectives under Art. 3(2), (3) and (5) TEU can serve as a basis of application of the 352 TFEU and objective under 3(1) TEU shall be excluded from this framework ${ }^{56}$ and the provision: "cannot serve as a basis for widening the scope of Union powers beyond the general framework created by the provisions of the Treaties as a whole and, in particular, by those that define the tasks and the activities of the Union." 57

54 Opinion of 28 March 1996, 2/94, EU:C:1996:140.

55 Opinion of 18 December 2014, 2/13, EU:C:2014:2454.

56 Declaration no 41 on Article 352 of the Treaty on the Functioning of the European Union (OJ C 326, 26 October 2012, p. 352).

57 Declaration no 42 on Article 352 of the Treaty on the Functioning of the European Union (OJ C 326, 26 October 2012, p. 353). 
The possibility of using Art. 352 TFEU (then Art. 308 of the Treaty establishing the European Community (hereinafter "TEC") for the conclusion of agreement on human rights was also rejected by the ECJ in its Opinion $2 / 94^{58}$ and outlawed widening the scope of the EU powers "beyond the general framework created by the provisions of the Treaty as a whole". Indeed, it can be argued that Opinion 2/94 was also relying on argument of necessity of "structural" changes of the system of the protection of human rights and therefore there is no other comparable process to accession to the ECHR. Although the agreement on business and human rights likely won't change institutional framework of protection of human rights in the EU, it changes paradigms of understanding of the framework for the protection of the human rights. Will of the Member States as creators of the Treaties does not seem to enshrine EU acceding to such instrument, providing powerful critique of such intentions to its opponents. At the time of conclusion of the Treaty of Lisbon, the Member States were aware of limits of application of then-Art. 308 TEC, with explanation given by Opinion 2/94. In wording of Art. $6 \mathrm{TEU}$, they decided to allow accession to ECHR only, not human rights agreements in general. Hence, the Member States did not allow to expand potential conclusion of international agreements regarding human rights in general under Art. 352 TFEU, but only within the framework given by existing policies of the EU. On the other hand, some authors see Art. 352(1) TFEU as a possible legal basis for international agreements on human rights (E.g. Nakanishi, 2018: 18), arguing that competence under Art. 308 TEC was employed for establishing the European Agency for Fundamental Rights. ${ }^{59}$

The harmonization provision (Art. $114 \mathrm{TFEU}$ ) is another flexible provision of Treaties that must be contemplated when concluding an international treaty. Compared to Art. 352(1) TFEU, it is much narrower and focuses on objectives of the internal market (Art. 26 TFEU) and it can be hardly used as a sole legal basis in the field of human rights. However, it can be used for removal of obstacles to internal market stemming from uneven application of rules and standards, including those that may be linked to human rights protection.

The Treaties contain several provisions that enshrine some aspects of the protection and promotion of human rights, including the prohibition of discrimination and measures adopted to combat it under Art. 19 TFEU. Accession of the EU to United Nations Convention on the Rights of Persons with Disabilities ${ }^{60}$ is

58 Opinion of 28 March 1996, 2/94, EU:C:1996:140, paragraphs 29-30.

59 Council Regulation (EC) No 168/2007 of 15 February 2007 establishing a European Union Agency for Fundamental Rights (OJ L 53, 22 February 2007, p. 1).

60 Council Decision of 26 November 2009 concerning the conclusion, by the European Community, of the United Nations Convention on the Rights of Persons with Disabilities (OJ L 23, 27 January 2010, p. 35). 
an important example of such treaty focused on specific aspects of human rights. In this case, the legal basis for the agreement was based on anti-discrimination provisions. The Council very carefully established the list of legal instruments that "illustrate the extent of the area of competence of the Community in accordance with the Treaty establishing the European Community." ${ }^{61}$ This approach of the Council may be understood as recognition of limited scope of the EU competences in the sphere of human rights, and necessity to rely on specific provisions establishing policies of the $\mathrm{EU}$ when assessing existence of competence, in contrast with deriving it from general principles.

Finally, powers to conclude international agreement can be found in the provisions covering area of freedom, security and justice, particularly provisions on cooperation in criminal matters and police cooperation (De Vido, 2017: 83; Nakanishi, 2018). The rationale of this approach can be sought in the link between protection of human rights and combat against crime, protection of rights of individuals in criminal procedure, or rights of the victims of crime. Since definition and protection of certain aspects of human rights is implied part of combatting crime, including violations of human rights, we can call this approach "implied implied" external competence of the EU in human rights, i.e. competence derived as external from other internal competence (cf. Nakanishi, 2018: 17, where provisions of the TFEU on area of freedom, security and justice are read in a way enabling the EU broadly 'to negotiate and conclude international agreements on human rights'.)

This approach is currently being tested in relation to Council of Europe Istanbul Convention on Preventing and Combating Violence against Women and Domestic Violence, adopted in 2011 (hereinafter "Istanbul Convention"). The Council of the EU opted to decide on signature by two separate decisions, within two separate powers of the EU: matters related to judicial cooperation in criminal matters, i.e. Art 82(2) and 83(1) TFEU, ${ }^{62}$ and asylum and non-refoulement rules, i.e. Art. 78(2) TFEU. ${ }^{63}$ Alongside legal basis identified by the

61 Council Decision of 26 November 2009 concerning the conclusion, by the European Community, of the United Nations Convention on the Rights of Persons with Disabilities (OJ L 23, 27 January 2010, p. 35), Annex II.

62 Council Decision (EU) 2017/865 of 11 May 2017 on the signing, on behalf of the European Union, of the Council of Europe Convention on preventing and combating violence against women and domestic violence with regard to matters related to judicial cooperation in criminal matters (OJ L 131, 20 May 2017, p. 11).

63 Council Decision (EU) 2017/866 of 11 May 2017 on the signing, on behalf of the European Union, of the Council of Europe Convention on preventing and combating violence against women and domestic violence with regard to asylum and non-refoulement (OJ L 131, 20 May 2017, p. 13). 
Council in its decisions, De Vido suggested other legal sources of protection of women against domestic violence: Art. 19 TFEU on a basis that violence against women is a form discrimination and Art. 168(1) TFEU on a basis that domestic violence can lead to physical and mental illness and diseases or be a source thereof (De Vido, 2017). However, the Istanbul Convention became a politically controversial instrument, and several EU countries opposed its ratification. Slovak parliament, for one, refused to ratify the Istanbul convention on a basis that it may violate Slovak constitution, defining marriage as a union of man and woman, and due to possibility of ambiguous interpretation of "stereotyped gender roles". ${ }^{64}$ Moreover, the Slovak government was obliged to take all measures to avoid accession of the EU to the Istanbul Convention. ${ }^{65}$

The Istanbul Convention however met similar challenges in various other countries as well, regarding ratification, implementation, or resistance to its very conceptual approach or terminology (see, e. g. Allwood, 2016; Ketelaars, 2019). As a result of these controversies, as well as approach of the Council in seeking a legal basis for accession to the Istanbul Convention, the European Parliament requested CJEU for opinion (1/19). ${ }^{66}$ Although it will be necessary to wait for the final opinion of the CJEU, it can be nevertheless expected that international agreement regarding business and human rights can become equally controversial as the Istanbul Convention (contested points being again e.g. cultural and economic differences between geopolitical blocks throughout the world, or allegations of exporting western values) and can therefore follow similar political struggle across the EU. The ideological discord regarding the Istanbul Convention may be considered as evidence of the EU and its Members States still being more "united in diversity" than

64 Decision of the National Council of the Slovak Republic No 1697 of 29 March 2019 https://bit.ly/3C6EGQi, accessed 1 June 2020.

65 Resolution of the Government of the Slovak Republic No 15 of 15 January 2020. https://bit.ly/3C5mgzb; accessed 1 June 2020.

66 Following questions were submitted to the Court:

“- Do Articles 82(2) and 84 TFEU constitute appropriate legal bases for the act of the Council relating to the conclusion, in the name of the European Union, of the Istanbul Convention, or must that act be based on Articles 78(2), 82(2) and 83(1) TFEU, and is it necessary or possible to separate the decisions concerning the signature and the conclusion of the convention as a consequence of that choice of legal basis?

- Is the conclusion by the European Union of the Istanbul Convention, in accordance with Article 218(6) TFEU, compatible with the Treaties in the absence of mutual agreement between all the Member States concerning their consent to be bound by that convention?" 
"united" regarding understanding social systems, solidarity and relationships between business, workers and society (E.g. Macková, 2018). The recent opinion of Advocate General Hogan, greenlighting the Council to conclude the Istanbul Convention, ${ }^{67}$ may serve as an important clarification of EU competences, but is unlikely to solve these underlying problems.

Elements of responsibility of business to respect human rights, including right to healthy environment and fair labour conditions, are currently embedded in EU legislation on "due diligence" and "corporate governance". These rules represent a possible solution for compelling business to respect (and protect) human rights not only within the EU, but also by their subsidiaries and supply chains. The body of instruments adopted in this area refer to possible legal basis for "implied implied" external competence to conclude international agreement on business and human rights (Smit et al., 2020a: 232 et seq.). In particular, these instruments rely on Art. 16 TFEU, ${ }^{68}$ Art. 50(1) TFEU, ${ }^{69}$ Art. 191(1) TFEU, ${ }^{70} 207$ TFEU. ${ }^{71}$

Since there is no comprehensive and precise legal framework containing competence of the EU conclude international agreement on business and

67 Opinion of Advocate General Hogan of 11 March 2021, 1/19, EU:C:2021:198.

68 Regulation (EU) 2016/679 of the European Parliament and of the Council of 27 April 2016 on the protection of natural persons with regard to the processing of personal data and on the free movement of such data, and repealing Directive 95/46/EC (General Data Protection Regulation) (OJ L 119, 4 May 2016, p. 1).

69 Directive 2014/95/EU of the European Parliament and of the Council of 22 October 2014 amending Directive 2013/34/EU as regards disclosure of non-financial and diversity information by certain large undertakings and groups (OJ L 330, 15 November 2014, p. 1).

70 Regulation (EU) No 995/2010 of the European Parliament and of the Council of 20 October 2010 laying down the obligations of operators who place timber and timber products on the market (OJ L 295, 12 November 2010, p. 23); Directive 2008/99/ EC of the European Parliament and of the Council of 19 November 2008 on the protection of the environment through criminal law (OJ L 328, 6 December 2008, p. 28); Directive 2004/35/EC of the European Parliament and of the Council of 21 April 2004 on environmental liability with regard to the prevention and remedying of environmental damage (OJ L 143, 30 April 2004, p. 56); Directive 2012/18/EU of the European Parliament and of the Council of 4 July 2012 on the control of major-accident hazards involving dangerous substances, amending and subsequently repealing Council Directive 96/82/EC (OJ L 197, 24 July 2012, p. 1).

71 Regulation (EU) 2017/821 of the European Parliament and of the Council of 17 May 2017 laying down supply chain due diligence obligations for Union importers of tin, tantalum and tungsten, their ores, and gold originating from conflict-affected and high-risk areas (OJ L 130, 19 May 2017, p. 1). 
human rights, neither express nor implied, the EU can rely merely on provisions that are at least indirectly linked to protection of human rights. Legal framework or the area of freedom, security and justice apparently provides the most suitable gateway for introduction of purely human rights international agreements into the EU legal order. However, this approach is under the scrutiny of the CJEU, and the resulting opinion will be highly consequential for future of the instrument within the EU.

\section{COMPETENCE OF THE EU REGARDING THE "THIRD REVISED DRAFT"}

Considering the current wording of the Third Revised Draft, it is apparent that this instrument at least partially may fall into the competence of the EU. Art. 4 of the Third Revised Draft (Rights of Victims) and Art. 5 thereof (Protection of Victims) can be linked to Art. 82(2)(c) TFEU, Art. 9 (Adjudicative Jurisdiction), 11 (Applicable Law), and 12 (Mutual Legal Assistance and International Judicial Cooperation) of the Third Revised Draft can be covered by Art. 81(2)(a)-(g) and 82(1)(b) TFEU.

While TFEU covers judicial cooperation in both civil and criminal matters, protection of "victims" is limited to the understanding of "victim" in the context of criminal law, i.e., "victims of crime". Although the notion of "victim" can be flexibly expanded (e.g., covering family members of a person whose death was directly caused by crime ${ }^{72}$ ), it cannot escape from the scope of Art. 83 TFEU, i.e., victim of criminal offence. The Third Revised Draft introduces broader definition of "victim" as a person or group of persons "suffered harm that constitute human rights abuse, through acts or omissions in the context of business activities" [Art. 1(1)]. The broad notion of "human rights abuse"73 allows to also cover persons who suffered harm due to deprivation of enjoyment of some of human rights that was not caused by criminal offence. Possible rights of these victims of "non-criminal abuses" can be enshrined in measures assuring "effective access to justice" [Art. 81(2)(e) TFEU]. The scope of competence of the EU under Art. 81 and 82 TFEU is moreover

Art. 2(1)(a)(ii) of Directive 2012/29/EU of the European Parliament and of the Council of 25 October 2012 establishing minimum standards on the rights, support and protection of victims of crime, and replacing Council Framework Decision 2001/220/JHA (OJ L 315, 14 November 2012, pp. 57-73).

73 "....any direct or indirect harm in the context of business activities, through acts or omissions, against any person or group of persons, that impedes the full enjoyment of internationally recognized human rights and fundamental freedoms, including the right to a safe, clean, healthy and sustainable environment." [Art. 1(2)]. 
limited by the requirement of a "cross-border" element for exercise of EU's powers.

The Draft Due Diligence Directive showed that the EP is at least willing to accept introduction of mandatory due diligence regimes regarding business and human rights (Art. 6 of the Third Revised Draft). Such regimes may be covered by powers related to internal market freedoms (Art. $50 \mathrm{TFEU}$ ) and minimal definitions of criminal offences [83(2) TFEU].

Even the institutional framework envisaged by the Third Revised Draft seems to be favourable to contemplate accession of the EU to the prospective agreement. Under Art. 19 thereof, it is open to signature to regional integration organizations and includes voting rights in the Committee to be established by the prospective agreement. On the other hand, final wording of provisions creating powers of the Committee, including interpretation of the instrument [Art. 15(4)(a)] are critical for compatibility of envisaged agreement with the EU law, based on the arguments similar to those laid down in the CJ EU opinion in the ECHR accession case. ${ }^{74}$ Similar objections can be raised regarding provisions related to effects of other international instruments. Although the original wording of Art. 12(6) of the Revised Draft was substantially modified in the Third Revised Draft [Art. 14 (5)], it may still require precedence over the EU Treaties, in contravention of the CJ EU case-law.

Notwithstanding possible competence of the EU in the field of area of freedom, security and justice, wording of Art. 3(3) of the Revised Draft may still undermine any effort to conclude the agreement by the EU Member States and the EU itself. Determining the scope rationae materiae of future convention on issue like business and human rights by having reference to "all human rights" was definitely unclear and insufficient. The agreement can create "structural" changes to the system of protection of human rights in the wording of Opinion 2/94, because it could open the EU to indefinite catalogues of human rights, resulting in problems of fragmentation of recognized human rights and subsequent crisis of authority, as outlined above.

This possible objection was partially solved by the new wording of the Art. 3(3) of the Second Revised Draft that shall "cover all internationally recognized human rights and fundamental freedoms emanating from the Universal Declaration of Human Rights, any core international human rights treaty and fundamental ILO convention to which a state is a party, and customary international law." This solution was only partial from the point of view of the EU. It truly adjusted the indefinite scope of previous version of the draft, but the scope of human rights of the EU is still limited by the

74 Opinion of 18 December 2014, 2/13, EU:C:2014:2454. 
Charter and the ECHR under Art. 6 TEU, and different scope in the future instrument is bound to raise difficulties not only in interpretation, but in assessing the competence of the EU to conclude such an instrument itself. On the other hand, the wording suggested in the Third Revised Draft can increase feasibility of the instrument by states, since it shall "cover all internationally recognized human rights and fundamental freedoms binding on the State Parties of this (Legally Binding Instrument), including those recognized in the Universal Declaration of Human Rights, the ILO Declaration on Fundamental Principles and Rights at Work, all core international human rights treaties and fundamental ILO Conventions to which a State is a Party, and customary international law." Therefore, the scope of the Third Revised Draft can fit into the scope of the human rights of the EU as are fenced by Art. 6 TEU. In this context, the Third Revised Draft suggests Art. 19(3) an Istanbul-Convention-like approach, i.e., the EU can accede to such a treaty merely within its conferred competence. This option may also allow the EU accession to such agreement, to the extent of rights established by the Charter. Such form of a "mixed accession", however, also requires all Member States of the EU in order make the agreement workable within the ambit of the EU.

\section{ADOPTION BY DIRECTIVES?}

Apart from the accession to any legally binding international document, the EU can incorporate its essential part into its internal legislation. Following table shows areas of the Third Revised Draft that are already, at least partially, covered by the EU legislation (or can be covered, subject to change of the respective acts), or are included in the EP's Draft Due Diligence Directive:

\begin{tabular}{|c|c|c|}
\hline Area covered & Third Revised Draft & EU legislation \\
\hline Rights of victims & Art. 4 & $\begin{array}{c}\text { Directive } 2012 / 29 / \mathrm{EU}^{75}, \\
\text { Art. } 3 \text { to } 17\end{array}$ \\
\hline Protection of victims & Art. 5 & $\begin{array}{c}\text { Directive } 2012 / 29 / \mathrm{EU}, \\
\text { Art. } 18 \text { to } 24\end{array}$ \\
\hline Prevention & Art. 6 & $\begin{array}{c}\text { Draft Due Diligence } \\
\text { Directive, Art. } 19 \text { et seq. }\end{array}$ \\
\hline
\end{tabular}

75 Directive 2012/29/EU of the European Parliament and of the Council of 25 October 2012 establishing minimum standards on the rights, support and protection of victims of crime, and replacing Council Framework Decision 2001/220/JHA (OJ L 315, 14 November 2012, p. 57). 


\begin{tabular}{|c|c|c|}
\hline Area covered & Third Revised Draft & EU legislation \\
\hline Liability - civil remedies & Art. 8(4) & $\begin{array}{l}\text { Due Diligence Directive, } \\
\text { Art. } 9,10 \text { and } 19\end{array}$ \\
\hline $\begin{array}{l}\text { Liability - criminal/ } \\
\text { administrative sanctions }\end{array}$ & Art. 8(3) & $\mathrm{JHA}$ directives $^{76}$ \\
\hline $\begin{array}{l}\text { Jurisdiction and choice } \\
\text { of court }\end{array}$ & Art. 9 & Brussels $\mathrm{I} b i s^{77}$ \\
\hline Applicable law & Art. 11 & $\begin{array}{c}\text { Rome } \mathrm{II}^{78} \text {, Draft Due } \\
\text { Diligence Directive, Art. } 20\end{array}$ \\
\hline Statute of limitations & Art. 10 & $\begin{array}{l}\text { Draft Due Diligence } \\
\text { Directive, Art. 19(4) }\end{array}$ \\
\hline
\end{tabular}

Therefore, the EU can introduce certain aspects of corporate responsibility for human rights abuses within the ambit its conferred competence, however this solution lacks global legal and political impact of international treaty. Indeed, the EU can turn the tables and introduce the substantive measures for protection human rights in business sphere not via negotiated international treaty, but unilaterally via the so-called the Brussels effect (Bradford, 2012).

\section{CONCLUSIONS}

Efforts to establish framework for legal responsibilities of business entities for violation of human rights trace back several decades. In 2014,

76 E.g. Directive 2011/36/EU of the European Parliament and of the Council of 5 April 2011 on preventing and combating trafficking in human beings and protecting its victims, and replacing Council Framework Decision 2002/629/JHA (OJ L 101, 15 April 2011, p. 1-11), Directive 2011/93/EU of the European Parliament and of the Council of 13 December 2011 on combating the sexual abuse and sexual exploitation of children and child pornography, and replacing Council Framework Decision 2004/68/JHA (OJ L 335, 17.12.2011, p. 1-14), Directive 2008/99/EC of the European Parliament and of the Council of 19 November 2008 on the protection of the environment through criminal law (OJ L 328, 6 December 2008, pp. 28-37).

77 Regulation (EU) No 1215/2012 of the European Parliament and of the Council of 12 December 2012 on jurisdiction and the recognition and enforcement of judgments in civil and commercial matters (OJ L 351, 20 December 2012, pp. 1-32).

78 Regulation (EC) No 864/2007 of the European Parliament and of the Council of 11 July 2007 on the law applicable to non-contractual obligations (Rome II) (OJ L 199, 31 July 2007, p. 40). 
the unprecedented attempt was launched within the HRC by establishing working group required to elaborate "an international legally binding instrument on transnational corporations and other business enterprises with respect to human rights". This effort was not welcomed by all states and the HRC appeared to be divided, while the EU Member States did not support the idea. In 2018, the working group introduced the "Zero Draft" - prospect of possible legally binding instrument (revised in 2019 and 2020) that has since been revised multiple times, but the consensus remains to be found. In this context, the EU found itself in an ideological trap. On the one hand, the EU is legally obliged to promote human rights in international relations. Furthermore, protection of human rights is a common value of the EU and the Member States. On the other hand, this initiative was launched also by countries that are criticized for lesser standard of protection of human rights and rule of law broadly, not merely in relation to transnational corporations. After several years of hesitation, the EU and its Member States engage again more active role. The only way for the EU to escape possible situation that it will be manoeuvred into human rights agreement designed by non-EU countries with lower standards of protection of human rights, is to take substantially active role to shape the final text of agreement in line with terms of the EU law. Indeed, such approach can lead to failure of the whole project (which is also a realistic outcome, having regard to irreconcilable positions of members of international community).

Further possible obstacle to feasibility of accession of the EU to such agreement is existence of competences within the EU. Certainly, the EU itself need not be a party to that agreement. Nonetheless, parallel systems of protection of human rights in the EU within the framework and simultaneously outside of that framework is definitely not the desired situation (considering EU's effort to access human rights conventions, such as ECHR or Istanbul Convention). There is no general expressed competence of the EU to conclude international agreements solely on protection of human rights. Values and objectives of the EU appeared not to be sufficient legal basis for conclusion of an international agreement. Equally, the EU institutions shall be careful in extension of their powers under Art. 352 TFEU. Neither there is an evident implied external competence, although it is possible to derive such competence from other provisions of the Treaties. Particularly Art. 19 TFEU and provisions on the area of freedom, security and justice can be considered a suitable framework for accession to human rights agreements, including international treaty on business and human rights, as being currently drafted within the HRC. All this legal basis of the competence of the EU in issue is, nevertheless, too fragile, and challengeable by the Member States that are 
currently more and more watchful in protection of their sovereign area of competence, as was documented in the case of Istanbul Convention.

Even if the EU overcomes all these perils, it is still not certain that crucial industrial players of the world (e.g., the US, China, Russia, India) will join the same path and all efforts for international enactment of responsibility of business will remain mere shadows and mirrors. This cannot prevent the EU to be world's leader in protection and promotion of human rights creating true "area of freedom, security and justice" and to pave its own secure path by proactive export of its values via its own international instruments and regulation of business activities on its territory. The EU can (and shall) accommodate business responsibility for violation of human rights notwithstanding the territory where such acts are committed. Notably, the EU is already comfortable with extraterritorial effects of its rules, e.g., non-discrimination rules of internal market, competition rules. Nevertheless, once the EU transfers such approach into the area of business and human rights, depending on the precise content of the treaty, it can either make a powerful impact on worldwide legal landscape of the issue, or break the authority EU holds internationally in protecting human rights standards, due to recklessly utilized competence conferred upon it by Member States.

\section{Bibliography}

Aaronson, S. A. (2009). Minding the United done Our Business: What has States Government to Ensure and can do Multinationals Foreign Markets Act Responsibly in Foreign Markets. Journal of Business Ethics, 59 (1/2), 175-198. Available at: https://doi.org/10.1007/s10551-005-3414-z.

Abe, O. (2016). Untying The Gordian Knot: Re-Assessing The Impact Of Business And Human Rights Principles On Extractive Resource Governance In Sub-Saharan Africa. American University International Law Review, 32 (4), 895-930. Available at: https://bit.ly/3myolNG.

Addo, M. K. (2014). The Reality of the United Nations Guiding Principles on Business and Human Rights. Human Rights Law Review, 14 (1), 133-147. Available at: https://doi.org/10.1093/hrlr/ngt041.

Adeyeye, A. (2007). Corporate Responsibility in International Law: Which Way to Go? Singapore Yearbook of International Law, 11, 141-161. Available at: https:// doi.org/10.1093/jiel/jgl048.

Allwood, G. (2016). Gender-based violence against women in contemporary France: domestic violence and forced marriage policy since the Istanbul Convention. Modern \& Contemporary France, 24 (4), 377-394. Available at: https://doi.org/ $10.1080 / 09639489.2016 .1203886$. 
Alston, P. (2005). The 'Not-a-Cat' Syndrome: Can the International Human Rights Regime Accommodate Non-State Actors? In P. Alston (ed.). Non-State Actors and Human Rights (pp. 3-36). Oxford: Oxford University Press.

Alvarez, J. E. (2011). Are Corporations "Subjects" of International Law ? Santa Clara Journal of International Law, 9 (1), 1-36. Available at: https://bit.ly/3uT24xJ.

Augenstein, D., Dawson, M. and Thielbbrger, P. (2017). Implementing the UNGPs in the European Union: Towards an Open Method of Coordination for Business and Human Rights. European University Institute Department of Law Research Paper (2017/01). Available at: https://doi.org/10.2139/ssrn.2905619.

Bartels, L. (2014). The EU's Human Rights Obligations in Relation to Policies with Extraterritorial Effects. European Journal of International Law, 25 (4), 10711091. Available at: https://doi.org/10.1093/ejil/chu071.

Bilchitz, D. (2016). The Necessity for a Business and Human Rights Treaty. Business and Human Rights Journal, 1 (2), 203-227. Available at: https://doi. org/10.1017/bhj.2016.13.

Bishop, J. D. (2012). The limits of corporate human rights obligations and the rights of for-profit corporations. Business and Human Rights, 22 (1), 74-104. Available at: https://doi.org/10.4337/9781781005774.00009.

Borlini, L. (2018). The EU's Promotion of Human Rights and Sustainable Development through PTAs as a Tool to Influence Business Regulation in Third Countries. In A. Bonfanti (ed.). Business and Human Rights in Europe (pp. 71-83). Available at: https://doi.org/10.4324/9780429443169-7.

Bradford, A. (2012). The Brussels effect. Northwestern University Law Review, 107 (1), 1-68. Available at: https://doi.org/10.1093/oso/9780190088583.003.0003.

Bright, C., Marx, A., Pineau, N., and Wouters, J. (2020). Toward a Corporate Duty for Lead Companies to Respect Human Rights in Their Global Value Chains? Business and Politics, 22 (4), 667-697. Available at: https://doi.org/10.1017/ bap.2020.15.

Brodská, J. and Scheu, H. C. (2018). The European Union and its Member States and the implementation of the UN Guiding Principles on Business and Human Rights. In P. Šturma and V. A. Mozetic (eds.). Business and Human Rights (pp. 152-165). Passau: Waldkirchen: rw\&w Science \& New Media.

Cameron, L. (2006). Private military companies: their status under international humanitarian law and its impact on their regulation. International Review of the Red Cross, 88 (863), 573-598. Available at: https://doi.org/10.1017/ S1816383106000683.

Cavanna, P. (2019). Blending Together Human Rights Due Diligence with 'Criminal' Law: Opportunities and Pitfalls of the Italian Solution. In A. Bonfanti (ed.). Business and Human Rights in Europe. International Law Challenges (pp. 122-132). Abington: Routledge. Available at: https://doi.org/10.4324/978042944316911.

Ciacchi, A. C. (2019). The direct horizontal effect of EU fundamental rights. European Constitutional Law Review, 15 (2), 294-305. Available at: https://doi. org/10.1017/S1574019619000154. 
Clapham, A. (2006). Human Rights Obligations of Non-State Actors. Oxford: Oxford University Press. Available at: https://doi.org/10.1093/acprof:oso/9780199288465.001.0001.

Clapham, A. (2008). Extending International Criminal Law Beyond the Individual to Corporations and Armed Opposition Groups. Journal of International Criminal Justice, 6 (5), 899-926. Available at: https://doi.org/10.1093/jicj/mqn076.

Clough, J. (2008). Punishing the Parent: Corporate Criminal Complicity in Human Rights Abuses. Brooklyn Journal of International Law, 33, 899-931. Available at: https://bit.ly/3mBjAmE.

Colangelo, A. J. (2016). The Frankenstein's Monster of Extraterritoriality Law. American Journal of International Law Unbound, 110, 51-56. Available at: https://doi.org/10.1017/S2398772300002397.

De Schutter, O. (2008). Corporate social responsibility European style. European Law Journal, 14 (2), 203-236. Available at: https://doi.org/10.1111/j.14680386.2007.00411.x.

De Vido, S. (2017). The ratification of the Council of Europe Istanbul Convention by the EU: A step forward in the protection of women from Violence in the European legal system. European Journal of Legal Studies, 9 (2), 69-102.

Deva, S. (2012). Human Rights Violations: A Case for Extraterritorial Regulation. In C. Luetge (ed.). Handbook of the Philosophical Foundations of Business Ethics (pp. 1077-1090). Cham, Suiza: Springer Nature. Available at: https://doi. org/10.1007/978-94-007-1494-6_62.

Douglas-Scott, S. (2011). The European Union and Human Rights after the Treaty of Lisbon. Human Rights Law Review, 11 (4), 645-682. Available at: https:// doi.org/10.1093/hrlr/ngr038.

Drahn, P. (2020). Adoption of EU Business and Human Rights Policy: The Use of Discretion in the National Transposition of EU Directives. Cham, Suiza: Springer Nature. Available at: https://doi.org/10.1007/978-3-030-46935-1.

Enneking, L. (2014). The Future of Foreign Direct Liability? Exploring the International Relevance of the Dutch Shell Nigeria Case. Utrecht Law Review, 10 (1), 44-54. Available at: https://doi.org/10.18352/ulr.256.

Fabri, H. R. (2014). Is there a case - legally and politically - for direct effect of WTO obligations? European Journal of International Law, 25 (1), 151-173. Available at: https://doi.org/10.1093/ejil/chu014.

Gillard, E. C. (2006). Business goes to war: Private military/security companies and international humanitarian law. International Review of the Red Cross, 88 (863), 525-572. Available at: https://doi.org/10.1017/S1816383107000768.

Government of Finland. (2019). Perspectives Paper; Business and Human Rights Towards a Common Agenda for Action.

Grear, A. (2007). Challenging Corporate 'Humanity': Legal Disembodiment, Embodiment and Human Rights. Human Rights Law Review, 7 (3), 511-543. Available at: https://doi.org/10.1093/hrlr/ngm013.

Grear, A., and Weston, B. H. (2015). The Betrayal of Human Rights and the Urgency of Universal Corporate Accountability: Reflections on a Post-Kiobel 
Lawscape. Human Rights Law Review, 15 (1), 21-44. Available at: https://doi. org/10.1093/hrlr/ngu044.

Hazenberg, J. L. J. (2016). Transnational Corporations and Human Rights Duties: Perfect and Imperfect. Human Rights Review, 17 (4), 479-500. Available at: https://doi.org/10.1007/s12142-016-0417-3.

Herlin-Karnell, E. (2011). EU values and the shaping of the international legal context. In D. Kochenov and F. Amtenbrink (eds.). The European Union's Shaping of the International Legal Order (pp. 89-107). Available at: https://doi. org/10.1017/CBO9781139519625.008.

Herlin-Karnell, E. (2012). The EU as a Promoter of Values and the European Global Project. German Law Journal, 13 (11), 1225-1246. Available at: https://doi. org/10.1017/s207183220001782x.

Horvathy, B. (2017). Value promotion and europeanisation by EU trade agreements. Bratislava Law Review, 1 (1), 84-94. Available at: https://doi.org/10.46282/ blr.2017.1.1.59.

International Corporate Accountability Roundtable, and European Coalition for Corporate Justice. (2014). Assessments of Existing National Action Plans (NAPS) on Business and Human Rights. Available at: https://bit.ly/3oMxLYC.

International Labour Organization. (2017). Tripartite Declaration of Principles concerning Multinational Enterprises and Social Policy. Available at: https://bit. ly/2YwSuop.

Irving, E. (2019). Suppressing Atrocity Speech on Social Media. AJIL Unbound, 113, 256-261. Available at: https://doi.org/10.1017/aju.2019.46.

Jacur, F. R. (2018). Corporate social responsibility in recent bilateral and regional free trade agreements: An early assessment. European Foreign Affairs Review, 23 (4), 463-483.

Janney, J. J., Dess, G. and Forlani, V. (2009). Glass Houses? Market Reactions to Firms Joining the UN Global Compact. Journal of Business Ethics, 90 (3), 407-423. Available at: https://doi.org/10.1007/s10551-009-0052-x.

Jeney, P. (2015). Judicial Enforcement of World Trade Organization Rules before the Court of Justice of the European Union. ELTE Law Journal, (1), 83-89.

Jerbi, S. (2009). Business and human rights at the UN: What might happen next? Human Rights Quarterly, 31 (2), 299-320. Available at: https://doi.org/10.1353/ hrq.0.0068.

Ji, M. (2015). Multinational Enterprises' Liability for the Acts of Their Offshore Subsidiaries: The Aftermath of Kiobel and Daimler. Michigan State International Law Review, 23 (2), 397-435.

Jonge, A. de. (2011). Transnational Corporations and International Law. Cheltenham, Northampton:EdwardElgar.Availableat:https://doi.org/10.4337/9780857930392. Jørgensen, K. E. and Wessel, R. A. (2011). The position of the European Union in (other) international organizations: Confronting legal and political approaches. In P. Koutrakos (ed.). European Foreign Policy: Legal and Political Perspectives (pp. 261-286). Cheltenham: Edward Elgar Publishing. 
Kaleck, W. and Saage-Maaß, M. (2010). Corporate Accountability for Human Rights Violations Amounting to International Crimes. Journal of International Criminal Justice, 8 (3), 699-724. Available at: https://doi.org/10.1093/jicj/ mqqO43.

Kelly, M. J. (2016). Ending Corporate Impunity for Genocide: The Case Against China's State-Owned Petroleum Company in Sudan. Oregon Law Review, 90, 413-448.

Kerikmäe, T. and Nyman-Metcalf, K. (2018). Less is More or More is More? Revisiting Universality of Human Rights. International and Comparative Law Review, 12 (1), 39-56. Available at: https://doi.org/10.1515/iclr-2016-0077.

Ketelaars, E. (2019). Geographical value spaces and gender norms in post-Maidan Ukraine: the failed ratification of the Istanbul Convention. Review of International Studies, 45 (5), 731-747. Available at: https://doi.org/10.1017/ S0260210519000287.

King, B. (2001). The UN Global Compact: Responsibility for Human Rights, Labor Relations, and the Environment in Developing Nations. Cornell International Law Journal, 34 (3), 481-485. Available at: https://bit.ly/3oXc5JF.

Kinley, D. and Chambers, R. (2006). The UN Human Rights Norms for Corporations: The Private Implications of Public International Law. Human Rights Law Review, 6 (3), 447-497. Available at: https://doi.org/10.1093/hrlr/ngl020.

Kinley, D. and Tadaki, J. (2004). From Walk to Talk: The Emergence of Human Rights Responsibilities of Corporations at International Law. Virginia Journal of International Law, 44, pp. 931-1023. Available at: https://ssrn.com/ abstract $=923360$.

Klein, W. E. J. (2016). Can We Trust For-Profit Corporations to Protect Our Privacy? [Commentary]. IEEE Technology and Society Magazine, 35 (3), 17-20. Available at: https://doi.org/10.1109/MTS.2016.2592780.

Kolieb, J. (2013). Australia : The Great Southern Land of Corporate Accountability? Prospects of Human Rights Litigation Against Corporate Bad-Actors in Australian Courts. Pandora's Box, 20, 61-71. Available at: https://bit.ly/3Dm498t.

Kolieb, J. (2014). Kiobel v Royal Dutch Shell: A Challenge for Transnational Justice. Macquare Law Journal, 13, 169-177.

Kontorovich, E. (2014). Kiobel Surprise : Unexpected by Scholars but Consistent With International Trends. Notre Dame Law Review, 89 (4), 1671-1694.

Krajewski, M. (2012). The Reform of the Common Commercial Policy. In A. Biondi, P. Eeckhout, and S. Ripley (eds.). EU Law after Lisbon (p. 436). New York: Oxford University Press. Available at: https://doi.org/10.1093/acprof:oso/9780199644322.003.0014.

Łazowski, A. and Wessel, R. A. (2015). When Caveats Turn into Locks: Opinion 2/13 on Accession of the European Union to the ECHR. German Law Journal, 16 (1), 179-212. Available at: https://doi.org/10.1017/S2071832200019477.

Leisinger, K. M. (2017). Capitalism with a human face: The UN global compact. Globalization and Corporate Citizenship: The Alternative Gaze: A Collection of Seminal Essays, (28), 178-202. Available at: https://doi.org/10.4324/9781351284240. 
Letnar Černič, J. (2009). Corporate responsibility for human rights: Analyzing the ILO Tripartite Declaration of Principles Concerning Multinational Enterprises and Social Policy. Miskolc Journal of International Law, 6 (1), 24-34. Available at: http://ssrn.com/abstract=1459548.

Letnar Černič, J. (2018). European Perspectives on the Business and Human Rights Treaty Initiative. In J. Letnar Černič and N. Carrillo-Santarelli (eds.). The Future of Business and Human Rights (pp. 229-250). Available at: https://doi. org/10.1017/9781780686455.012.

Lysina, P. (2018). Medzinárodná zmluva ako nástroj vonkajšej činnosti Európskej únie. Bratislava: Wolters Kluwer SR.

Macková, Z. (2018). Wither the social security and the welfare state in the 21 st century - A relic or necessity? Bratislava Law Review, 2 (2), 163-170. Available at: https://doi.org/10.46282/blr.2018.2.2.114.

Marullo, M. C., and Zamora Cabot, F. J. (2016). Transnational Human Rights Litigations. Kiobel's touch and concern: A test under construction. In El Tiempo de los Derechos (vol. 1). Available at: https://bit.ly/2ZXLf9w.

McCorquodale, R. (2003). Pluralism, Global Law and Human Rights: Strengthening Corporate Accountability for Human Rights Violations. Global Constitutionalism, 2 (2), 287-315. Available at: https://doi.org/10.1017/ S2045381713000099.

McCorquodale, R. and Simons, P. (2007). Responsibility beyond Borders: State Responsibility for Extraterritorial Violations by Corporations of International Human Rights Law. The Modern Law Review Limited, 70 (4), 598-625. Available at: https://doi.org/10.1111/j.1468-2230.2007.00654.x.

Methven O’Brien, C. (2018). The Home State Duty to Regulate the Human Rights Impacts of TNCs Abroad: A Rebuttal. Business and Human Rights Journal, 3 (1), 47-73. Available at: https://doi.org/10.1017/bhj.2017.29.

Milliard, T. S. (2003). Overcoming Post-Colonial Myopia: A Call to Recognize and Regulate Private Military Companies. Military Law Review, 176, 1-95.

Mills, A. (2014). Rethinking Jurisdiction in International Law. British Yearbook of International Law, 84 (1), 187-239. Available at: https://doi.org/10.1093/ bybil/bru003.

Miretski, P. P. and Bachmann, S.-D. (2012). The UN 'Norms of the Responsibility of Transnational Corporation and Other Business Enterprises with Regard to Human Rights': A Requiem. Deakin Law Review, 17 (1), 5-41. Available at: https://doi.org/10.21153/dlr2012vol17no1art68.

Mokrá, L. (2020). Relations of EU and other international organisations. In European Union foreign policy: External dimension of European Union in area of human rights and development (pp. 178-192). Bratislava: Univerzita Komenského v Bratislave.

Mokrá, L. (2021). Internal dimension of human rights law in the EU. Praha: C. H. Beck.

Mokrá, L. and Janková, K. (2018). EU as a human rights actor? Bratislava Law Review, 2 (2), 91-105. Available at: https://doi.org/10.46282/blr.2018.2.2.117. 
Muchlinski, P. (2021). The Impact of the un Guiding Principles on Business Attitudes to Observing Human Rights. Business and Human Rights Journal, 6 (2), 212-226. Available at: https://doi.org/10.1017/bhj.2021.14.

Müller-Graff, P.-C. (2017). Legal Europeanization Outside the European Union. Bratislava Law Review, 1 (1), 6-14. Available at: https://doi.org/10.46282/ blr.2017.1.1.67.

Murphy, S. D. (2005). Taking multinational corporate codes of conduct to the next level. Columbia Journal of Transnational Law, 43 (2), 389-434.

Nakanishi, Y. (2018). Mechanisms to Protect Human Rights in the EU's External Relations. In Y. Nakanishi (ed.). Contemporary Issues in Human Rights Law: Europe and Asia (pp. 3-21). Available at: https://doi.org/10.1007/978-981-106129-5_1.

Nolan, A. (2009). Addressing Economic and Social Rights Violations by Non-state Actors through the Role of the State: A Comparison of Regional Approaches to the 'Obligation to Protect'. Human Rights Law Review, 9 (2), 225-255. Available at: https://doi.org/10.1093/hrlr/ngp007.

Nolan, J. (2005a). The United Nations' Compact with Business: Hindering or Helping the Protection of Human Rights? The University of Queensland Law Journal, 24 (2), 445-467.

Nolan, J. (2005b). With Power Comes Responsibility: Human Rights and Corporate Accountability. University of New South Wales Law Journal, 28 (3), 581-613.

Nowrot, K. (2011). Transnational Corporations as Steering Subjects in International Economic Law: Two Competing Visions of the Future? Indiana Journal of Global Legal Studies, 18 (2), 803-842. Available at: https://doi.org/10.2979/ indjglolegstu.18.2.803.

Palombo, D. (2019). The Duty of Care of the Parent Company: A Comparison between French Law, UK Precedents and the Swiss Proposals. Business and Human Rights Journal, 4 (2), 265-286. Available at: https://doi.org/10.1017/ bhj.2019.15.

Palombo, D. (2020). Business and Human Rights. The Obligations of the European Home States. Hart Publishing. Available at: https://doi.org/10.5040/9781509928064.

Pariotti, E. (2009). International Soft Law, Human Rights and Non-state Actors: Towards the Accountability of Transnational Corporations? Human Rights Review, 10 (2), 139-155. Available at: https://doi.org/10.1007/s12142-0080104-0.

Percy, S. (2012). Regulating the private security industry: A story of regulating the last war. International Review of the Red Cross, 94 (887), 941-960. Available at: https://doi.org/10.1017/S1816383113000258.

Peters, A., Förster, T. and Koechlin, L. (2009). Towards Non-State Actors as Effective, Legitimate, and Accountable Standard-Setters. In A. Peters, L. Köchlin, T. Förster, and G. Fenner (eds.). Non-State Actors as Standard Setters (pp. 544-584). Available at: https://doi.org/10.1017/CBO9780511635519. 
Reinisch, A. (2005). The Changing International Legal Framework for Dealing with Non-State Actors. In P. Alston (ed.). Non-State Actors and Human Rights (pp. 37-92). Available at: https://bit.ly/3ajF41K.

Reynders, D. (2020). Speech by Commissioner Reynders in RBC Webinar on Due Diligence. Avilable at: https://bit.ly/2WTiidT.

Rubin, S. J. (1995). Transnational Corporations and International Codes of Conduct: A Study of the Relationship Between International Legal Cooperation and Economic Development. American University International Law Review, 10 (4), 1275-1289. Available at: https://bit.ly/3DowJGe.

Ruggie, J. (2007). Business and Human Rights: The Evolving International Agenda. The American Journal of International Law, 101 (4), 819-840. Available at: https://doi.org/10.2307/40006320.

Ruiz Galán, J. (2016). Búsqueda De Consensos Sobre Empresas Y Derechos Humanos: Hacia Un Instrumento Internacional Vinculante. American University International Law Review, 32 (4), 819-857. Available at: https://bit.ly/2Yt7lk7.

Savourey, E. and Brabant, S. (2021). The French Law on the Duty of Vigilance: Theoretical and Practical Challenges Since Its Adoption. Business and Human Rights Journal, 6 (1), 141-152. Available at: https://doi.org/10.1017/bhj.2020.30.

Scheimer, M. (2009). Separating Private Military Companies From Illegal Mercenaries in International Law: Proposing an International Convention for Legitimate Military and Security Support the Reflects Customary International Law. American University International Law Review, 24 (3), 609-646.

Schroeder, W. (2016). The EU Founding Values: Constitutional Character and Legal Implications. European Studies: the Review of European Law, Economics and Politics, 3, 45-62. Available at: https://doi.org/10.5771/9783845274843-45.

Sever, S. (2014). Horizontal effect and the charter. Croatian Yearbook of European Law and Policy, 10 (1), 39-65. Available at: https://doi.org/10.3935/ cyelp.10.2014.183.

Skinner, G. L. (2014). Beyond Kiobel: Providing Access to Judicial Remedies for Violations of International Human Rights Norms by Transnational Business in a New (post-Kiobel) World. Columbia Human Rights Law Review, 46, 158-265.

Slim, H. (2012). Business actors in armed conflict: Towards a new humanitarian agenda. International Review of the Red Cross, 94 (887), 903-918. Available at: https://doi.org/10.1017/S181638311300009X.

Smit, L., Bright, C., McCorquodale, R., Bauer, M., Deringer, H., Baeza- Breinbauer, D. Tejero \& Tobed, H. (2020a). Study on Due Diligence Requirements through the Supply Chain. Available at: https://doi.org/10.2838/39830.

Smit, L., Bright, C., Pietropaoli, I., Hughes-Jennett, J. and Hood, P. (2020b). Business views on mandatory human rights due diligence regulation: A comparative analysis of two recent studies. Business and Human Rights Journal, 5 (2), 261-269. Available at: https://doi.org/10.1017/bhj.2020.10.

Stehlík, V. (2019). The Court of Justice of the European Union Crossing the Rubicon on the Same-Sex Marriages? Commentary on Coman Case. International and 
Comparative Law Review, 18 (2), 85-99. Available at: https://doi.org/10.2478/ iclr-2018-0039.

Stoynov, V. (2017). The Direct Effect of EU Bilateral Trade Agreements Such as the Transatlantic Trade and Investment Partnership in the Light of the Jurisprudence of the Court of Justice of the European Union. Amsterdam Law Forum, 9 (1), 42. Available at: https://doi.org/10.37974/alf.289.

Swaine, E. T. (2016). Kiobel and Extraterritoriality: Here, (Not) There, (Not Even) Everywhere. Oklahoma Law Review, 69, 23-51. Available at: https:/doi. org/10.2139/ssrn.2958277.

UN Working Group on Business and Human Rights. (2016). Guidance on National Action Plans on Business and Human Rights. Available at: https://bit.ly/3lo4t0m.

United States Withdraws from the United Nations Human Rights Council, Shortly After Receiving Criticism About Its Border Policy. (2018). American Journal of International Law, 112 (4), 745-751. Available at: https://doi.org/10.1017/ ajil.2018.92.

Vazquez, C. M. (2005). Direct vs. Indirect Obligations of Corporations Under International Law. Columbia Journal of Transnational Law, 43 (12), 922-960. Available at: http://scholarship.law.georgetown.edu/facpub/980.

Weissbrodt, D. and Kruger, M. (2003). Norms on the Responsibilities of Transnational Corporations and Other Business Enterprises with Regard to Human Rights. The American Journal of International Law, 97, 901-922. Available at: https://doi.org/10.2307/3133689.

Wennmann, A. (2012). The role of business in armed violence reduction and prevention. International Review of the Red Cross, 94 (887), 919-940. Available at: https://doi.org/10.1017/S1816383113000180.

Werhane, P. H. (2016). Corporate Moral Agency and the Responsibility to Respect Human Rights in the United Nations Guiding Principles: Do Corporations Have Moral Rights? Business and Human Rights Journal, 1 (1), 5-20. Available at: https://doi.org/10.1017/bhj.2015.1.

Wessel, R. A. (2016). The Meso Level: Means of Interaction between EU and International Law: Flipping the Question: The Reception of EU Law in the International Legal Order. Yearbook of European Law, 35 (1), 533-561. Available at: https://doi.org/10.1093/yel/yew019.

Wettstein, F. (2015). Normativity, Ethics, and the UN Guiding Principles on Business and Human Rights: A Critical Assessment. Journal of Human Rights, 14 (2), 162-182. Available at: https://doi.org/10.1080/14754835.2015.1005733.

White, N. D. (2016). Regulation of the Private Military and Security Sector: Is the UK Fulfilling its Human Rights Duties? Human Rights Law Review, 16 (3), 585-599. Available at: https://doi.org/10.1093/hrlr/ngw019.

Worster, W. T. (2016). Relative International Legal Personality of Non-State Actors. In Brooklyn Journal of International Law (42) 207. Available at: https://bit. ly/2YrDMik.

Zamfir, I. (2018). Towards a binding international treaty on business and human rights. European Parliament Briefing, April. Available at: https://bit.ly/3oEy8o9. 